BUILDING TECHNOLOGIES PROGRAM

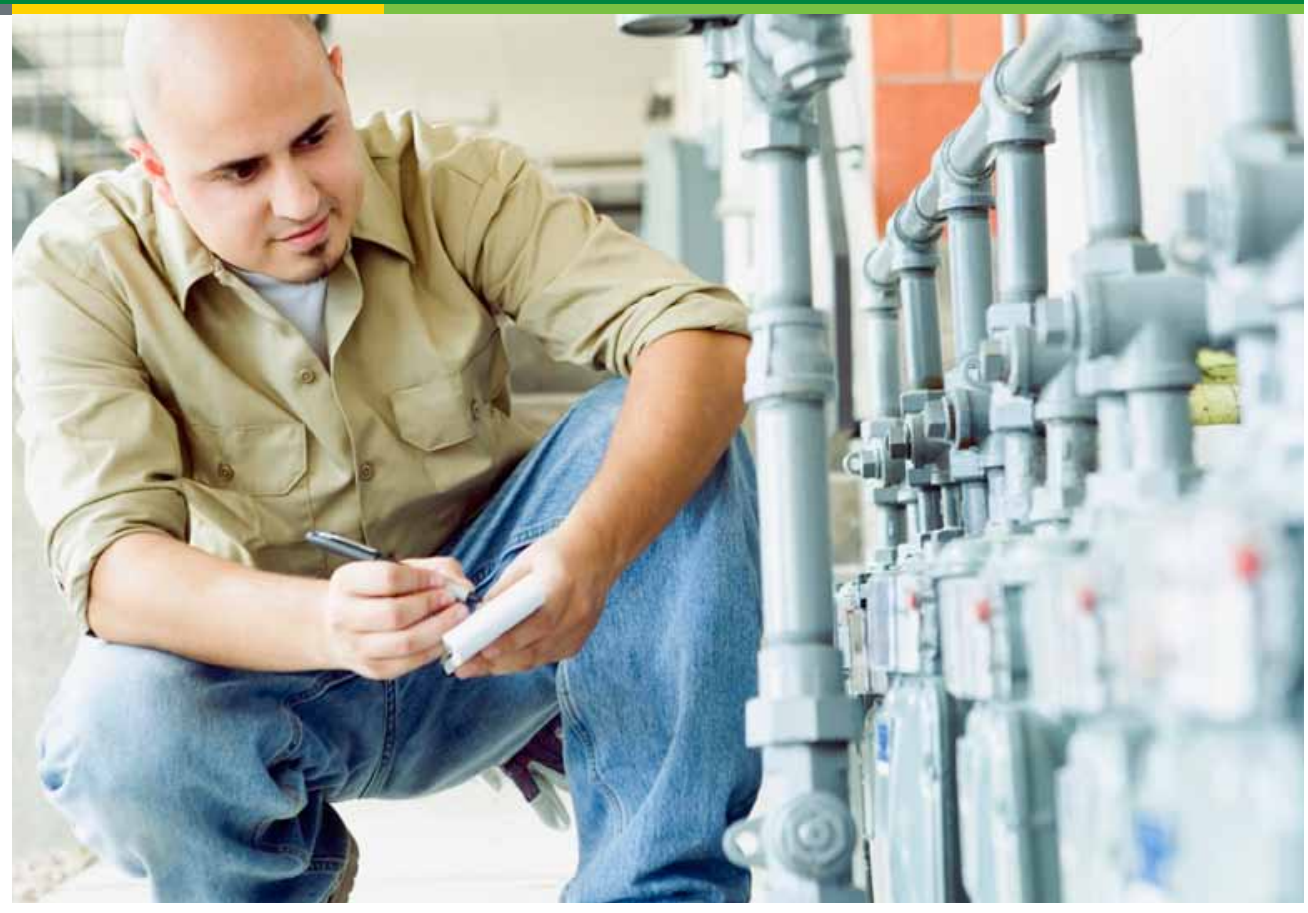

\title{
A Guide to Energy Audits
}




\section{BUILDING TECHNOLOGIES PROGRAM}

\section{A Guide to Energy Audits}

Prepared by

Pacific Northwest National Laboratory

Michael Baechler

Portland Energy Conservation, Inc.

Cindy Strecker, PE and Jennifer Shafer

September 25, 2011

Prepared for

U.S. Department of Energy

under Contract DE-AC05-76RL01830

PNNL-20956

Pacific Northwest National Laboratory

Richland, Washington 99352

This report was prepared as an account of work sponsored by an agency of the United States Government. Neither the United States Government nor any agency thereof, nor Battelle Memorial Institute, nor any of their employees, makes any warranty, express or implied, or assumes any legal liability or responsibility for the accuracy, completeness, or usefulness of any information, apparatus, product, or process disclosed, or represents that its use would not infringe privately owned rights. Reference herein to any specific commercial product, process, or service by trade name, trademark, manufacturer, or otherwise does not necessarily constitute or imply its endorsement, recommendation, or favoring by the United States Government or any agency thereof, or Battelle Memorial Institute. The views and opinions of authors expressed herein do not necessarily state or reflect those of the United States

Government or any agency thereof. 


\section{Contents}

A Guide to Energy Audits ...........................................................................

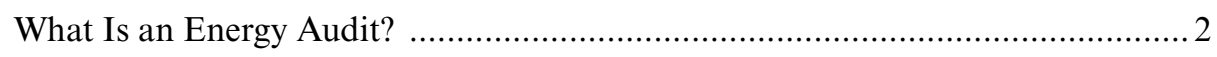

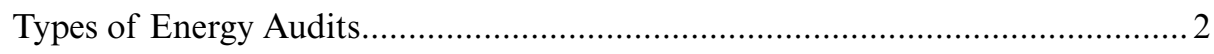

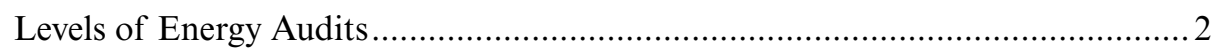

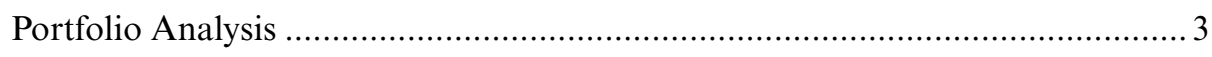

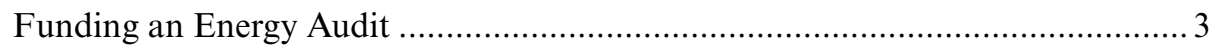

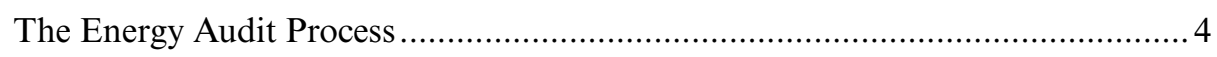

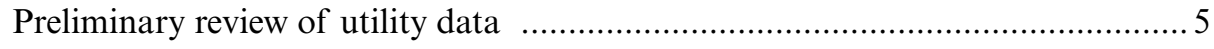

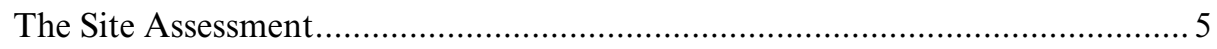

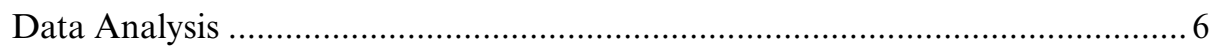

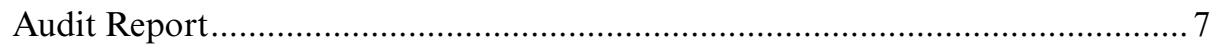

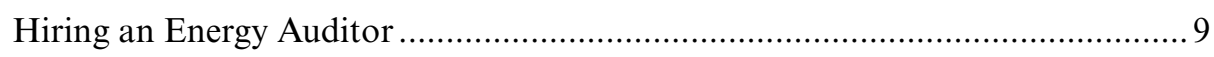

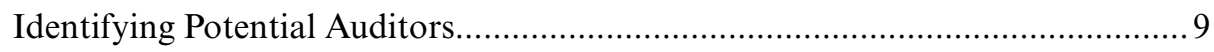

Requests for Qualifications and Requests for Proposals................................... 9

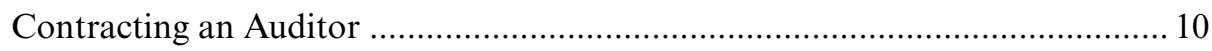

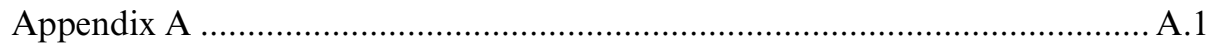

A Guide to Energy Audits: ....................................................................... A.1

Request for Qualifications ........................................................................ A.1

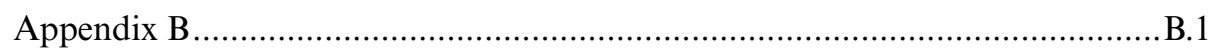

A Guide to Energy Audits: ........................................................................

Request for Qualifications....................................................................... B.

Energy Audit to Identify Energy Efficiency Projects ..................................... B.1

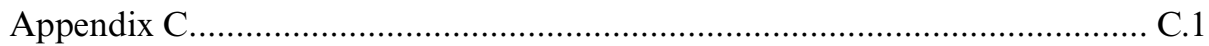

A Guide to Energy Audits: .......................................................................... C.1

Energy Audit Agreement ...................................................................... 


\section{A Guide}

\section{to Energy Audits}

Energy audits are a powerful tool for uncovering operational and equipment improvements that will save energy, reduce energy costs, and lead to higher performance. Energy audits can be done as a stand-alone effort but may be conducted as part of a larger analysis across a group of facilities, or across an owner's entire portfolio.

\section{ENERGY AUDITS IDENTIFY:}

- No-cost operational or maintenance adjustments that will save energy

- Short-term, low-cost energy efficiency retrofit recommendations

- Action plans for energy efficiency capital investments

- Comfort and code issues that can be addressed immediately

- Opportunities for better adherence to lighting and comfort standards
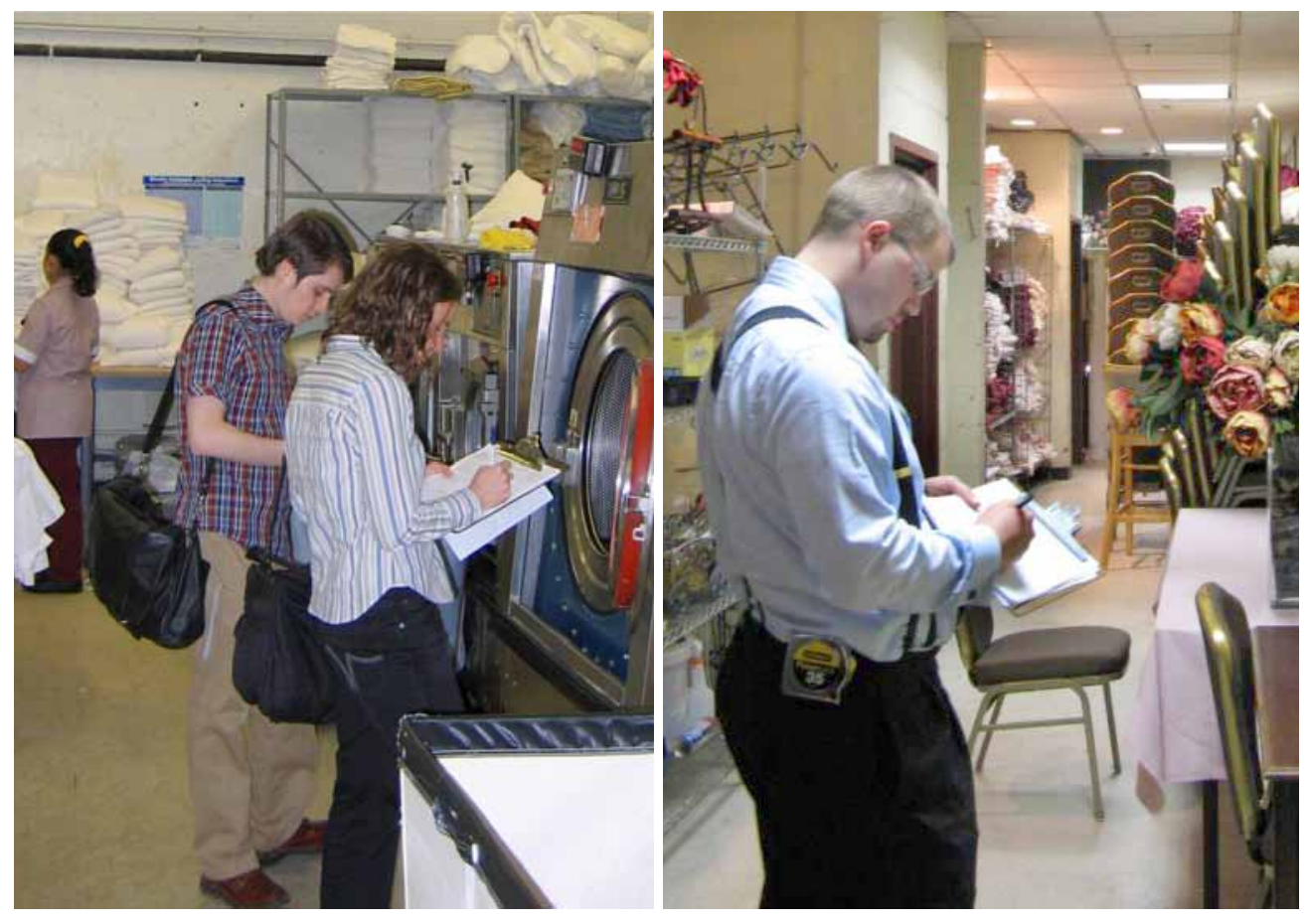

Simple energy audits equip building owners with a list of no-cost or low-cost recommendations and a general road map for future planning. Many of these recommendations are easily implemented by operations and maintenance staff, and energy savings are seen almost immediately. Resulting cost savings can then be put toward future energy efficiency projects.

More complex energy audits provide a comprehensive energy efficiency capital investment plan in line with a building owner's financial goals. This type of rigorous energy audit is typically part of a larger energy management program, and may include partnering with an energy services company to fully realize energy savings opportunities.

Whether you are looking for simple retrofits or a long-term investment project, an energy audit is the first step toward reducing energy use and improving the performance of facilities in your portfolio. This guide provides an overview of the energy audit process, including an overview of the different energy audit options available and information on how to select an energy auditor.
A convention center in a major metropolitan city reduced energy costs by almost $\$ 80,000$ annually by implementing energy efficient changes to equipment, controls and systems. Payback for these changes was less than a year, and facility staff predict an additional savings of $\$ 174,000$ annually if longer-term equipment replacements are installed ${ }^{1}$. 


\section{COMMON TERMS}

Energy efficiency measures (EEMs) adjustments to building systems and controls, or equipment installations that result in lower energy use

Energy services company (ESCO) - a

company that identifies energy

improvements, provides the capital

required to install improvements, offers

turn-key installation services, and

guarantees energy savings

Investment grade audit - a

comprehensive energy audit that seeks to

identify all cost-effective investment

opportunities through a combination of

engineering analysis of energy-using

systems and economic analysis of possible

energy saving measures
One system

All Systems and

System Interactions

Breadth of Audit

Simple analysis of one system and a narrow list of measures

Low cost, no cost

options

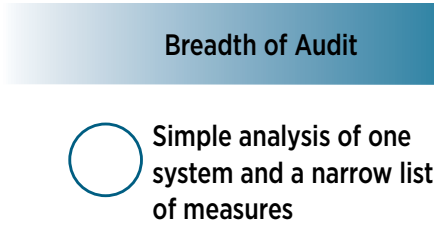

(2)

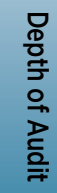

Facility-wide analysis with rigorous quantification of project costs and savings, and equipment specifications ready for bid documents

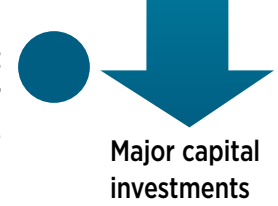

Range of potential audit breadth and depth

\section{What Is an Energy Audit?}

The purpose of an energy audit (sometimes called an "energy assessment" or "energy study") is to determine where, when, why and how energy is used in a facility, and to identify opportunities to improve efficiency. Energy auditing services are offered by energy services companies (ESCOs), energy consultants and engineering firms. The energy auditor leads the audit process but works closely with building owners, staff and other key participants throughout to ensure accuracy of data collection and appropriateness of energy efficiency recommendation.

The audit typically begins with a review of historical and current utility data and benchmarking of your building's energy use against similar buildings. This sets the stage for an onsite inspection of the physical building. The main outcome of an energy audit is a list of recommended energy efficiency measures (EEMs), their associated energy savings potential, and an assessment of whether EEM installation costs are a good financial investment.

\section{Types of Energy Audits}

Energy audits typically take a whole building approach by examining the building envelope, building systems, operations and maintenance procedures, and building schedules. Whole building audits provide the most accurate picture of energy savings opportunities at your facility.

Alternately, energy audits can be targeted to specific systems (i.e., lighting or heating, ventilation and air conditioning). Targeted audits may miss significant biggerpicture energy savings opportunities, but may be a good route if you have specific energy efficiency retrofit projects in mind and limited funds to invest.

\section{Levels of Energy Audits}

The American Society of Heating, Refrigerating and Air-Conditioning Engineers (ASHRAE) ${ }^{2}$ defines three levels of audits. Each audit level builds on the previous level. As audit complexity increases, so does thoroughness of the site assessment, the amount of data collected and the detail provided in the final audit report. This effort can translate into higher energy savings.

Level I: Site Assessment or Preliminary Audits identify no-cost and low-cost energy saving opportunities, and a general view of potential capital improvements. Activities include an assessment of energy bills and a brief site inspection of your building.

Level II: Energy Survey and Engineering Analysis Audits identify no-cost and low-cost opportunities, and also provide EEM recommendations in line with your financial plans and potential capital-intensive energy savings opportunities. Level II audits include an in-depth analysis of energy costs, energy usage and building characteristics and a more refined survey of how energy is used in your building.

Level III: Detailed Analysis of Capital-Intensive Modification Audits (sometimes referred to as an "investment grade" audit) provide solid recommendations and financial analysis for major capital investments. In addition to Level I and Level II activities, Level III audits include monitoring, data collection and engineering analysis.

The energy auditor you select will work with you to understand your project goals and available budget, and help you determine which level of audit you need. For smaller facilities where there is no major capital improvement plan or budget, a Level I audit could yield results that make the cost of the audit worthwhile. If 
you have a larger facility that has never been audited, a Level II or Level III audit would be more appropriate due to the complexities of systems and potential savings opportunities.

Level II and Level III audits are more expensive, but are good options if you have defined energy efficiency goals but not yet taken action, or if you have plans for a major renovation or equipment upgrade. These audits should include a preliminary feasibility study (often provided by potential energy auditors free of charge) to scope the energy saving opportunities and ensure that the cost of the energy audit is worth the savings payoff.

\section{Portfolio Analysis}

If you have a portfolio of buildings, work with your energy auditor to choose facilities that show the greatest potential for energy savings, and audit those facilities first. No-cost and low-cost EEMs identified through these audits may be applicable across all buildings in your portfolio.

The Facility Energy Decision System (FEDS, www.pnl.gov/FEDS), can also help you select good energy audit candidates from your building portfolio. FEDS is an easy-to-use tool that lets you quickly and efficiently evaluate building energy use and identify cost-effective savings opportunities. FEDS is free for federally-funded projects and projects funded and directly performed by a state government on a state-owned facility. Commercial building owners can use FEDS for a fee.

\section{Funding an Energy Audit}

The scope and level of detail of the energy audit can be a big driver in costs. Establishing criteria for cost-effectiveness prior to conducting the audit can help limit the scope to pursuing only viable projects.

Capital improvement and operation and maintenance budgets are key funding sources for energy audits. In some cases the cost of an energy audit can be seen as a temporary investment rather than a cost, due to the payback from implementing no-cost or low-cost energy savings measures recommended during the energy audit. In other cases, you may already have a capital improvement plan to replace an aging, inefficient chiller or to complete a major overhaul of your building's lighting system; an energy audit could direct the capital investment in the most cost-effective way and ensure that energy savings are maximized.

Other potential funding sources:

- ESCOs will finance and manage your energy efficiency improvement projects and share the energy savings. This is worth pursuing if you are considering significant installations.

- Utilities may offer incentives or partial funding for energy audits. Some utilities may even provide consultation during energy audits. Funds may also be available for installation of financially-viable energy efficiency measures.

Some non-profit organizations or product vendors may offer no-cost or low-cost audits. However, audits conducted by inexperienced staff, or vendor-sponsored audits geared toward a specific technology or product, may highlight simple individual energy efficiency recommendations but overlook other significant opportunities. Unqualified auditors may also provide recommendations that could result in no energy savings (or worse, increased energy usage or damage to your equipment).
Building owners wishing to simplify energy management efforts may opt to partner with an ESCO that will often provide feasibility studies free of charge to scope potential energy savings projects across a portfolio of facilities.

The process for hiring an ESCO is more complex than hiring an energy auditor. If you choose this route, two leading organizations that can help you get started are the National Association of Energy Services Companies (www.naesco. org) and the Energy Services Coalition (www.energyservicescoalition.org).

There are fixed costs associated with preparing an energy audit (site coordination, travel, field surveys and report generation), so economies of scale tend to apply for larger facilities.

Reported costs for detailed energy audits may vary from $\$ 0.12$ up to $\$ 0.50^{3}$ per square foot, depending on the size and complexity of the building.

Industry practice suggests that the cost of an energy audit should not exceed $10 \%$ of your annual utility bill. 


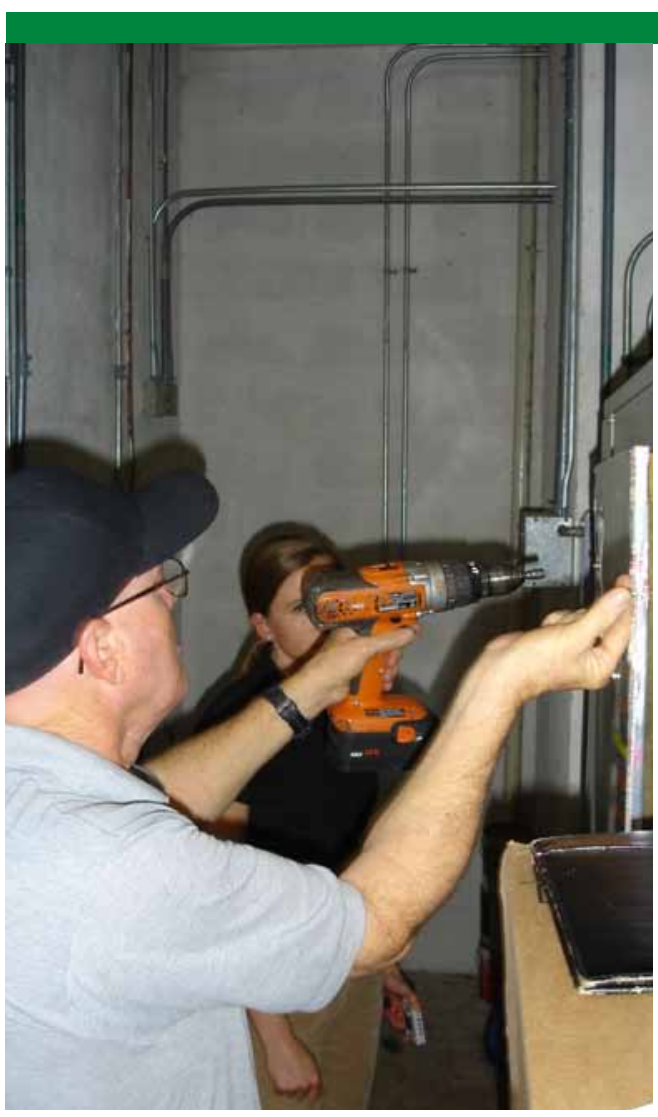

Cost is an important factor in selecting an energy auditor, but to ensure a quality audit, cost should not be the driving factor. Auditor experience, certifications and successful past project examples are other key considerations when choosing an energy auditor. More information on selecting an energy auditor can be found in the "Hiring an Energy Auditor" section of this guide.

\section{The Energy Audit Process}

The energy auditor leads each phase of the energy audit process, but the facility owner, key operations and maintenance staff, and controls contractor (if applicable) also play key roles and should be actively engaged throughout the entire process. Depending on your facility or business line, you may also need to involve legal, financial or branding staff in the process. In multi-tenant buildings, it may make sense to include influential tenants or occupants in the process if shared energy costs or building comfort issues are a potential concern. Identifying an internal project manager to oversee the project will help to ensure success.

Regardless of the audit level you choose or the number of facilities you wish to audit, the energy audit process is generally the same. The first step is to select an energy auditor and develop a contract. From there, phases of the energy audit include:

Companies may need to provide electricians or other staff to facilitate the audit.

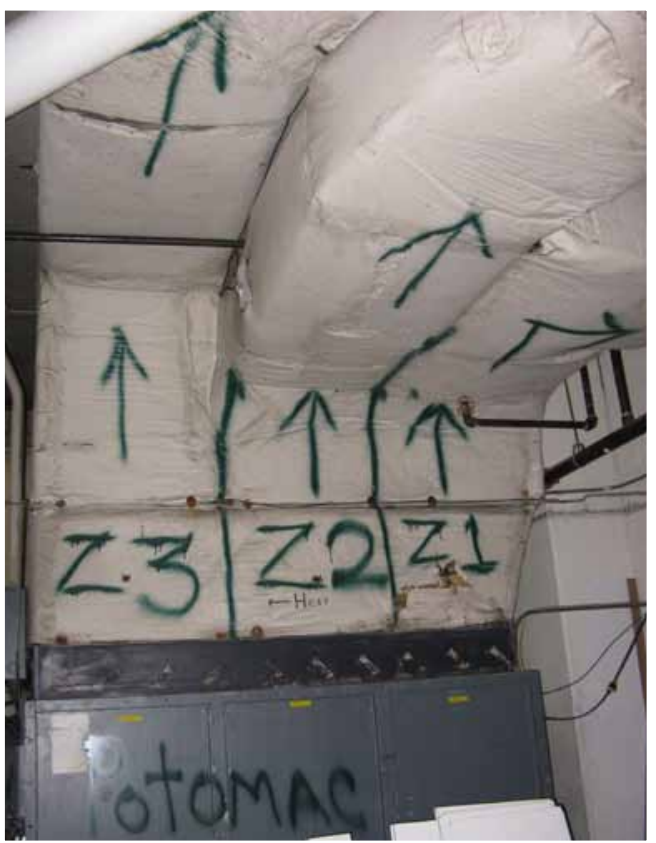

\begin{tabular}{|c|c|c|}
\hline Project phase & Project milestone(s) & Project activities \\
\hline $\begin{array}{l}\text { Preliminary review of } \\
\text { energy use }\end{array}$ & $\begin{array}{l}\text { - Facility benchmarked against } \\
\text { similar buildings } \\
\text { - Base energy load identified }\end{array}$ & $\begin{array}{l}\text { - Collect and analyze utility } \\
\text { data } \\
\text { - Calculate EUI and compare } \\
\text { to similar facilities } \\
\text { - Assess energy efficiency } \\
\text { improvement potential }\end{array}$ \\
\hline Site assessment & $\begin{array}{l}\text { - } \text { Site data collected } \\
\text { - Immediate energy savings } \\
\text { opportunities identified } \\
\text { - Exit meeting held to discuss } \\
\text { preliminary findings }\end{array}$ & $\begin{array}{l}\text { - Interview building staff } \\
\text { - Visually inspect building and } \\
\text { key systems } \\
\text { - Collect data }\end{array}$ \\
\hline $\begin{array}{l}\text { Energy and cost } \\
\text { analysis }\end{array}$ & $\begin{array}{l}\text { - EEMs prioritized according to } \\
\text { project and financial goals } \\
\text { - Savings estimates generated }\end{array}$ & $\begin{array}{l}\text { - Evaluate utility and site data } \\
\text { - Analyze energy and cost } \\
\text { savings } \\
\text { - Develop list of recom- } \\
\text { mended measures }\end{array}$ \\
\hline $\begin{array}{l}\text { Completion of audit } \\
\text { report }\end{array}$ & $\begin{array}{l}\text { - Exit meeting held to walk } \\
\text { through final report } \\
\text { - Action plan developed for } \\
\text { next steps }\end{array}$ & $\begin{array}{l}\text { - Summarize findings } \\
\text { - Present recommendations }\end{array}$ \\
\hline
\end{tabular}




\section{Preliminary review of utility data}

The energy auditor first performs a preliminary energy use evaluation by examining utility data, building or system diagrams, equipment lists, and other facility information. In general, the energy auditor should collect and review at least two years of utility data during the energy use analysis to account for seasonal variations and patterns of energy use. Monthly utility bill data is most commonly used; however, hourly or more frequent interval meter data is becoming more widely available from utilities. All forms of energy (electricity, gas, oil, water) should be included in this analysis.

From this evaluation, the energy auditor will calculate your facility's Energy Utilization Index (EUI) value (annual energy use/square footage) and energy end uses (energy used by each building system). The EUI and base energy load enable the energy auditor to benchmark this data against energy use of similar buildings and systems to illustrate the potential magnitude of energy efficiency opportunities and provide an early estimate of potential savings. The energy auditor also looks for any changes in energy use over time and potential causes for those changes.

The energy auditor will provide a preliminary report which includes a summary of data and graphs and other visuals to allow for easy interpretation. Results from this analysis can be helpful in determining which level of audit to perform; results also inform recommendations in the final audit report.

\section{The Site Assessment}

After the preliminary review, the energy auditor will conduct a physical assessment of your facility and its operations. During the site assessment the energy auditor will meet with key operations and maintenance staff to learn how your building operates and discuss any current concerns or issues with the facility.

The energy auditor will also conduct a visual inspection and inventory of the building's key elements, including:

- Construction details of the building envelope (e.g. walls, roof, windows, doors and related insulation values)

- An inventory of the heating and cooling systems (HVAC) capacities and rated efficiency

- Manual, timeclock or automated HVAC control methods

- Interior and exterior lighting systems and related controls

- Service hot water systems

Level I, Level II and Level III site assessments each include some degree of investigation into operations and maintenance procedures, schedules, and typical building occupancy. The duration of the onsite assessment varies depending on the level of audit you choose, and time commitments required from you and/or your staff may increase as you move from Level I audits (which could take as little as four to eight hours) to Level II and Level III audits (Level III audits in particular may require the auditor to conduct multiple site visits and meter equipment to capture usage data).

\section{BUILDING BASE ENERGY LOAD}

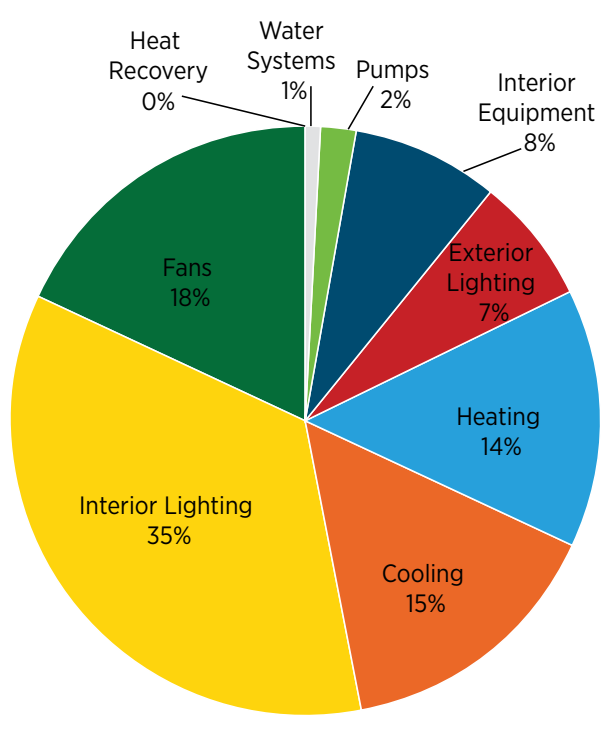

Sample energy end uses-can be indexed against similar building system average loads to identify energy savings opportunities.

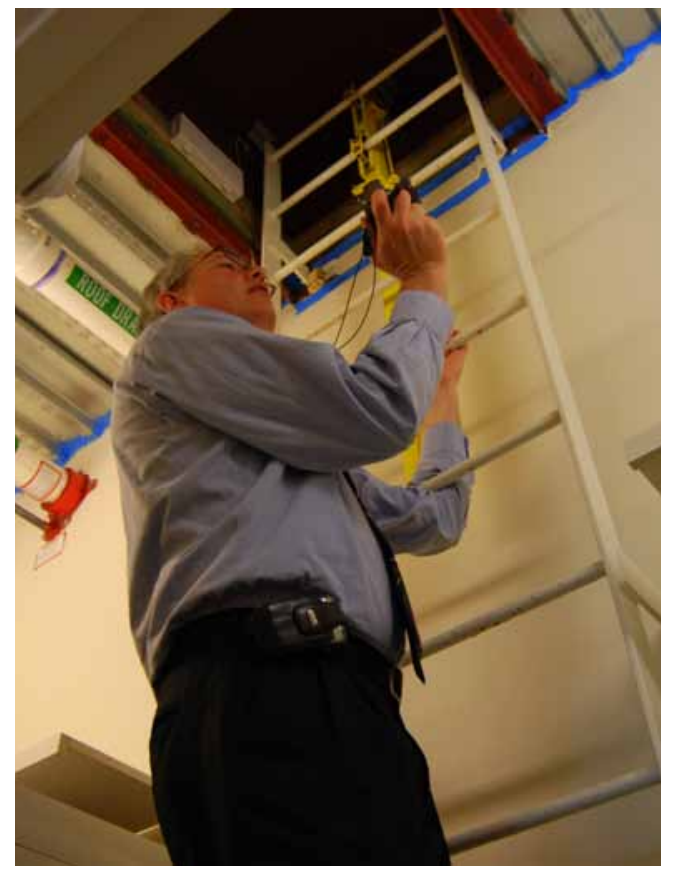

Auditors inspect all building components to develop recommendations for efficiency upgrades. 


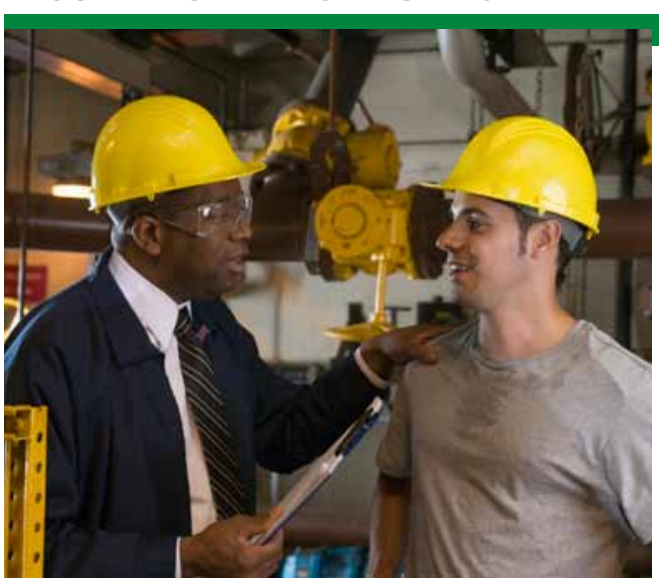

Staff and auditors need to discuss facility operations.
Building staff (facility managers, operations and management staff, key contractors as appropriate) should participate actively in the site assessment. Often the energy auditor can identify changes that building staff can implement immediately; building staff can also share their perspective on building conditions in the context of the physical review of equipment and systems. These interactions help to engage building staff in the energy audit process and encourage ownership of building maintenance and ongoing energy efficiency.

Prior to the site assessment, inform the energy auditor of any previous audits and recent or planned building improvements. Additionally, you may need to ensure in advance that the energy auditor has permission or security access to complete certain tasks such as photographing facility equipment, accessing machine rooms, or collecting data from controls systems.

At the conclusion of the site assessment, plan to hold an exit meeting with the energy auditor and key building staff to discuss preliminary findings, recommendations and feasibility of EEM implementation. This will help focus the next step of the process - data analysis.

\section{Data Analysis}

After the energy auditor has collected the necessary data for your building, they will begin the energy and cost analysis. Baseline energy use, data collected through the onsite assessment and financial impacts of energy efficiency measure installations are taken into account during the analysis. Before beginning the analysis, the energy auditor should have a good understanding of your economic methodology and business criteria to ensure that the analysis is fairly compared with other investment opportunities and that cash flows match expectations.

Energy analysis methodologies vary widely. Your project goals should inform the analysis methodology selected to avoid results that yield too much or too little detail. Typical analysis methodologies include spreadsheet analysis based on engineering formulas that account for variations in time of day and season, and whole-building hourly energy use analysis for larger buildings or buildings with complex mechanical systems. More complex methods used in Level II and Level III audits enable more accurate calculations of potential energy savings, but are also more costly.

The cost analysis considers current energy costs, measure implementation costs and potential savings over time help to determine practicality and priority of EEM recommendations. You should provide the financial method that the energy auditor will use to determine the order of EEM implementation. Examples of financial methods include simple payback period, life cycle cost, internal rate of return and discounted payback.

Accurate installation cost data is critical for the financial analysis. Underestimating costs could result in inadequate budgeting for energy efficiency improvements, while overestimating costs may cause facility decision makers to delay or deny an improvement project. The energy auditor should gather measure installation costs from a sample of vendors, and costs should include any specific considerations for your particular facility. Level II and Level III audits should include a detailed cost analysis to ensure valid economic analysis.

Additionally, utility incentives and tax credits for any recommended measures should be taken into consideration in any level of financial analysis. 
Using this analysis the energy auditor develops a list of recommended EEMs and generates savings estimates. The energy auditor then works with your project team to prioritize the list of practical measures. While EEMs are typically evaluated individually, when installed together some measures (such as premium efficiency motors and motor controls) produce total savings greater than the sum of the individual savings. In other cases, combined measures may reduce the savings potential. This "measure interaction" should be a consideration in the energy auditor's analysis.

Installing EEMs may also impact your building's operations. Aspects that should be considered when analyzing potential EEMs include:

- Operations and maintenance $(\mathrm{O} \& \mathrm{M})$ : Does the facility have the staff to ensure savings from the energy efficiency retrofit persist over time, and will the measure have a positive or negative effect on the O\&M costs?

- Comfort: Will the measure result in increased human comfort (and potentially lead to fewer maintenance calls)?

- Improved system reliability: Will the measure lead to lower contractor costs?

- Feasibility of system replacement: Are parts easily replaced, will installed technology be outdated in the near future?

- Ease of implementation: How will installation of the measure affect daily business operations? Are power outages required? Can the facility stay open during installation?

- Risk of failure: What are the operational, financial and safety impacts if the system fails?

Documentation of analysis methodology, assumptions, and supporting calculations should all be included with the savings estimates.

\section{Audit Report}

The energy auditor's main deliverable for the energy audit is the final report. Any audit report should provide enough information to allow you to make informed decisions about next steps to meet your energy savings and financial goals. Audit reports include an inventory of existing equipment, a summary of your building's current conditions and energy use, and a list of recommended no-cost, low-cost, and longer-term EEM recommendations based on analysis of historical energy use and the onsite assessment.

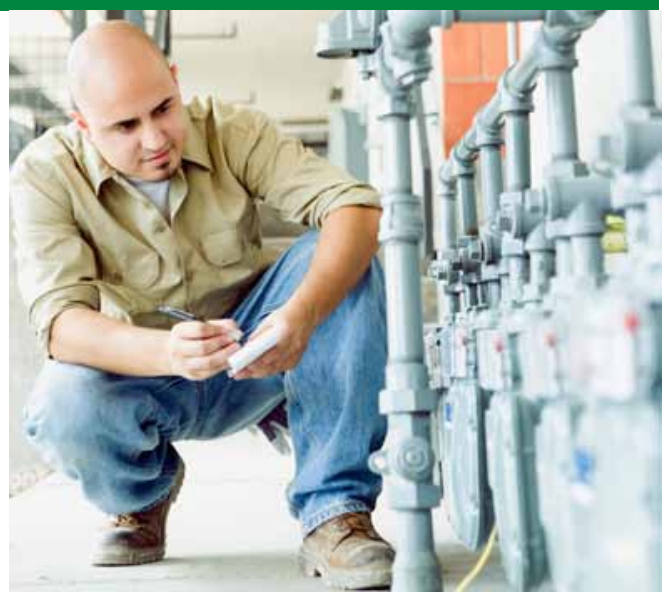

Auditors will need to collect utility data to determine building energy use.

An energy audit at a national department store identified several immediate improvement opportunities:

- The main fan system was running at a low speed, 24 hours a day, instead of shutting off completely when the store was unoccupied

- Two large electric heaters meant for freeze protection were set to 65 degrees, warming the ventilation air being brought in from outdoors, even when cooling was needed

Building staff quickly corrected both these situations, and upgrades to the building energy management system will help prevent them from occurring in the future. 


\begin{tabular}{|c|c|c|}
\hline $\begin{array}{l}\text { Level I Audit } \\
\text { Report }\end{array}$ & Level II Audit Report & Level III Audit Report \\
\hline $\begin{array}{l}\text { - Executive } \\
\text { - Summary } \\
\text { - Brief facilities } \\
\text { description } \\
\text { - Scope of audit/ } \\
\text { Methodology } \\
\text { - Preliminary } \\
\text { Analysis } \\
\text { Findings, includ- } \\
\text { ing benchmark } \\
\text { and end use } \\
\text { results } \\
\text { - List of no-cost } \\
\text { and low-cost } \\
\text { energy measures } \\
\text { - Potential mea- } \\
\text { sures for further } \\
\text { consideration }\end{array}$ & $\begin{array}{l}\text { - All items from Level I Audit } \\
\text { - More comprehensive energy end use } \\
\text { analysis } \\
\text { - Description of building systems and } \\
\text { major equipment } \\
\text { - Financial analysis of EEMs } \\
\text { - Description of energy efficiency } \\
\text { measures considered and not recom- } \\
\text { mended or not financially viable } \\
\text { - Description of energy efficiency } \\
\text { measures recommended } \\
\text { - Summary table with measure name, } \\
\text { installed cost, energy savings by utility, } \\
\text { and O\&M savings } \\
\text { - Capital Intensive measures requiring } \\
\text { Level IIl audit } \\
\text { - Detailed energy analysis calculations } \\
\text { Measurement and verification (M\&V) } \\
\text { plan for verifying energy savings }\end{array}$ & $\begin{array}{l}\text { - All items from Level II } \\
\text { - Dudit } \\
\text { Detailed information } \\
\text { on capital intensive } \\
\text { measures - including } \\
\text { schematics, equip- } \\
\text { ment lists, equipment } \\
\text { specifications, design } \\
\text { sequences and costs } \\
\text { - Highly detailed finan- } \\
\text { cial evaluation }\end{array}$ \\
\hline
\end{tabular}

Information available in Level I, Level II, Level III audit reports ${ }^{4}$

The majority of the report should focus on recommended EEMs. Typically, these are presented as no-cost or low-cost measures, practical measures meeting your financial criteria, and capital-intensive measures. The report should include detailed descriptions of each recommended EEM, and explain:

- Existing conditions and recommended changes, including equipment specs and specific locations of installations

- How the measure will save energy and how much energy it will save

- Financial analysis results including costs of recommended measures

- Effects on maintenance and comfort

The report should also present optimized bundles of measures, where shorter payback EEMs are combined with longer payback EEMs to collectively meet energy savings and financial goals. This may be of particular interest if your facility has significant deferred maintenance items.

An energy audit report could include a summary of utility incentives and rebates or tax credits available from energy efficiency installations. Some energy audit reports provide lists of quality energy efficiency products or vendors, making it easy for you or your contractors to upgrade to more energy efficient equipment.

Plan to hold a final meeting with the energy auditor and key building staff to review the final report. Audit reports, even when considered a useful investment, sometimes get pushed aside and forgotten leaving energy and cost savings unclaimed. At the final meeting, walk through the analysis, results and recommended EEMs. Discuss high-level next steps and a schedule for action. There may be operational changes you can implement immediately in one or more buildings in your portfolio that will result in instant energy savings. Other changes may need to be assessed further and incorporated into your longer-term plans. 


\section{Hiring an Energy Auditor}

The process for competitive selection of an energy auditor includes identifying potential auditors, defining the scope of work and requesting bids, assessing qualifications, and contracting with an auditor. Portions of these procedures may also be adopted by building managers who opt for the alternative, sole-source approach. Directly negotiating a scope and budget with a preferred vendor is likely to be the quickest path to an audit and offers the benefit of selecting a firm that has already proven its abilities. However, a more open and competitive process will offer insight into the range of qualifications and costs that are available within the field of firms that offer energy audits.

\section{Identifying Potential Auditors}

Not all firms advertising energy audits offer the same quality of service, and narrowing from the entire group of providers to a smaller group of qualified candidates requires some research. Knowing what to look for and where to begin looking will streamline this process.

Put simply, you will want to hire an auditor who understands how energy is used in your facility and who is well-versed in the method of energy auditing. The number and complexity of the systems that are included in the audit of a large facility mean that an auditing firm may employ a team of professionals, each contributing expertise in the different systems. For example, an audit of a large office building requires technical knowledge of building envelopes, control systems, HVAC, lighting, plug loads, and water heating and distribution systems. Buildings with specialized uses, such as laboratories and hospitals, may have additional systems requiring additional expertise.

In addition to technical understanding of the building's systems, the auditor must also have mastered the energy audit process. This requires knowledge of auditing tools, measure identification, and economic analysis. Many building engineers may have the system knowledge required for an audit, but fewer also have experience with the audit process. Energy auditing certifications provide evidence that an auditor has been trained in these other dimensions. Certified professionals can be identified through the websites of certifying organizations and through industry websites.

Your local utility and government agencies may also offer assistance, ranging from simply suggesting a qualified auditor to actually funding an audit.

\section{Requests for Qualifications and Requests for Proposals}

Unless your organization requires a formal request for proposals (RFP), you may select from your list of potential auditors using a request for qualifications (RFQ). A well executed RFQ will help you to select the auditor who is best suited for your project and obtain a competitive rate with less administrative burden than a formal proposal process.

The RFQ document introduces your project and your expectations for the audit process, and requests information from prospective firms about their relevant

\section{ENERGY AUDITING CERTIFYING ORGANIZATIONS}

- Organization: American Society of Heating, Refrigerating and AirConditioning Engineers

- Auditing Certification: Building Energy Assessment Professional

- Website: http://cms.ashrae.biz/ certification/ BEAP.php

- Organization: Association of Energy Engineers

- Auditing Certification: Certified Energy Auditor

- Website: www.aeecenter.org/custom/ cpdirectory/

- Organization: National Association of Energy Service Companies

- Auditing Certification: None

- Website: http://www.naesco.org/ providers/ 
Rebuild America ${ }^{5}$ reports that common energy efficient retrofit projects include:

- Lighting retrofits (replacing existing lighting with high efficiency fluorescents or LEDs; installing lighting controls; using task lighting instead of increasing ambient lighting levels; decrease installed capacity)

- HVAC equipment upgrades, ventilation and distribution system improvements, and controls optimizations

- Roof and wall insulation improvements

- Programmable thermostats

If you have requested sample audit reports, look for possible red flags:

- Measures with long paybacks recommended over measures with shorter paybacks

- Long paybacks for equipment with short life spans

- Narrow focus of recommended EEMs (e.g., only lighting measures are recommended, specific to a particular vendor)

- Minimal analysis to support large energy savings claims

- Incomplete or poorly documented project costs

Contacting references can be a great way to gain insight into an auditor's quality of work. Preparing a short list of key questions will balance your need for information with the previous customer's need to get on with their business. The following questions strike this balance:

- What was the scope of work performed?

- Who were the auditor's key personnel?

- Was the auditor responsive? Did the auditor stick to the schedule and budget?

- What were the audit results, in terms of estimated project costs and savings?

- If the recommendations were implemented, did the actual savings match the prediction?

- How satisfied were you with the overall quality of the audit and professionalism of the auditor? experience and fees. Selecting the right firm for your project is then a matter of comparing qualifications, fees, and references, combined with a phone or in-person interview.

Your RFQ document will be most effective if it provides enough information about your project to allow prospective auditors to give examples of similar work that they have successfully completed. Including a well-developed project description provides the interested firms with a level playing field for providing cost estimates. For larger or more complex facilities, allowing a site visit by the prospective auditors will also improve the quality of the submittals.

A sample RFQ which can be modified to meet the needs of your project team is provided as Appendix A. If you do require a more comprehensive selection process,

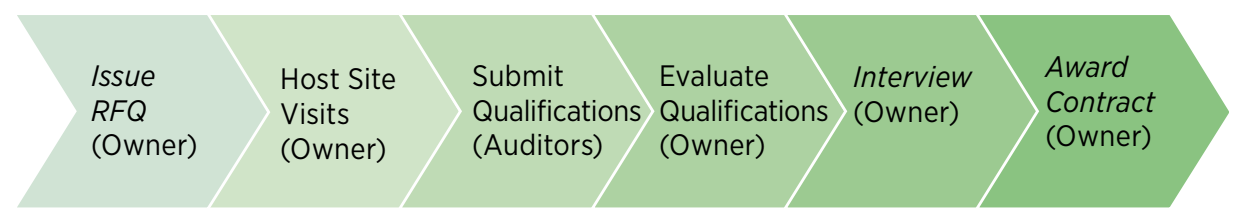

RFQ for an Auditor, identifying the lead for each activity

an RFP requires bidders to submit more detail on their organization as well as their approach to the project goals and scope of work. A sample RFP is provided as Appendix B.

Include the appropriate elements in the RFQ or RFP will help to ensure a relatively straightforward comparison of the prospective auditors' qualifications and fees. It is important to also consider the auditor's experience, certifications, and successful past project examples. Skilled energy auditors have years of field experience and know how to look for energy savings in and across building systems that less experienced auditors may overlook.

The evaluation of agents' qualifications begins after your potential candidates have replied to your RFQ or RFP. Evaluation includes a comparison of overall submissions, qualifications and fees, as well as reference checks. This is largely a comparative evaluation using weights provided in the RFQ or RFP, but it is wise to enforce minimum requirements as well. This will help avoid issues such as selecting an auditor with very low prices and a history of unsatisfied clients.

As a final step in the RFQ or RFP selection process, you may wish to interview the top ranked candidate(s). This will give you an additional opportunity to evaluate their professionalism and to ask any questions about qualifications, services, or costs that remain after review of the submittals.

\section{Contracting an Auditor}

Once an auditor has been selected, a contract is established to deliver a specified scope of auditing services. The contract with an auditor details the scope of work that they are expected to perform, the specific personnel assigned to your project, the project schedule and budget. It is also a good time to identify any support your team must provide to facilitate the audit. The project description from the RFQ or RFP will provide a starting point, but the contracting process provides an opportunity to negotiate a specific scope of work for the selected auditor tied to a maximum price. 
A detailed description of audit tasks and deliverables in the contract scope of work will help ensure that the audit delivers the information you need to take the next steps toward energy and cost savings. The scope should define what systems will be evaluated by the audit and the required rigor of the analysis. For very basic audits, information required could simply be a list of no-cost and low-cost measures that your facility staff can implement. The most detailed audits used to support major capital investments must provide much more information, such as equipment specifications, project costs, savings estimates and associated calculation details. Whatever your requirements, they should be clearly defined in the contract scope of work.

In addition to the scope of work, terms of compensation and schedule, an audit contract also typically includes standard language governing contract modifications, liability, use of information collected by the audit, and other legal rights of the parties. A sample contract for a detailed energy audit is provided in Appendix C. This sample can be modified to meet your specific contract requirements and should be subjected to your normal legal review and approval procedures.

\section{Additional Resources}

Whether you are looking for quick fixes or long-term energy investment opportunities, an energy audit is the first step. Not only will you gain immediate energy savings from no-cost opportunities, you will be well equipped to develop a plan for action for short-term as well as longer-term energy savings investments.

Regardless of how you choose to pursue energy efficient measures for your facility, resources are widely available. This guide explained the energy audit process and walked you through how to select an energy auditor. Here are some additional references to get you on your way toward energy savings at your facility:

- Association of Energy Engineers Certified Professionals Directory http://www. aeecenter.org/custom/cpdirectory

- California Energy Commission. How to Hire an Energy Auditor to Identify Energy Efficiency Projects (January, 2000). http://www.energy.ca.gov/reports/efficiency_handbooks/400-00-001C.PDF

- U.S. Department of Energy Commercial Building Partnerships - information on partnering with DOE representatives, national laboratory staff, and private-sector technical experts to explore energy-saving ideas and strategies in retrofit and new construction projects $h t t p: / / w w w 1 . e e r e . e n e r g y . g o v /$ buildings/commercial_initiative/ building_partnerships.html

- U.S. Department of Energy: Energy Efficiency \& Renewable Energy (extensive information on energy efficiency in buildings) http://www.eere.energy.gov/topics/buildings.htm/

\section{AT A MINIMUM, A RFQ OR RFP SHOULD INCLUDE:}

Project description

- Project goals, including

- Available budget

- Payback requirements

- Detailed description of facilities to be included in the audit, including

- Location

- Size

- Age

- Use

- Building systems

- Past facility upgrades, if any

- Current energy costs

- Audit requirements, including

- Level of analysis

(e.g. ASHRAE audit

level I, II or III)

- Deliverables

- Schedule

\section{Description of selection process}

- Required format of submittals, including

- Relevant project experience, including sample audits

(Weight: $\%)$

- Qualifications of key personnel (Weight: $\%)$

- Audit fees (Weight: -\%)

- Client references (Weight: $\%)$

- Opportunities for site visits

- Deadlines for submittals 


\section{Acknowledgements}

The information in this document is drawn from several existing guides and reports:

- American Society of Heating, Refrigeration and Air-Conditioning Engineers, Inc. (ASHRAE). Procedures for Commercial Building Energy Audits (2004). California Energy Commission. How to Hire an Energy Auditor to Identify Energy Efficiency Projects (January, 2000). http://www.energy.ca.gov/reports/efficiency_handbooks/400-00-001C.PDF

- Shapiro, Ian; 10 Common Problems in Energy Audits. ASHRAE Journal. 2011, Vol 53, no. 2, p. 26-32.

- USAID ECO-III Project. Energy Assessment Guide for Commercial Buildings (2009). http://www.emt-india.net/ECBC/ECBC-Guidebooks/Energy\%20Assessment\%20guide\%20for\%20Commercial\%20Buildings.pdf

- U.S. Department of Energy. Energy Savings Assessment Training Manual (2011). http://www1.eere.energy.gov/femp/pdfs/esa_manual.pdf

\section{Appendices}

A. Sample Energy Audit RFQ: Request for Qualifications Source: City of Lowell, MA Department of Planning and Development http://www.lowellma.gov/depts/dpd/projects/better-buildings/files/NewRFQ.pdf Accessed June 23, 2011

B. Sample Energy Audit RFP Source: California Energy Commission. How to Hire an Energy Auditor to Identify Energy Efficiency Projects (January, 2000). http://www.energy.ca.gov/reports/efficiency_handbooks/400-00-001C.PDF Accessed June 23, 2011

C. Sample Energy Audit Contract Source: Florida Department of Management Services http://www.dms.myflorida.com/media/facilities/forms_and_documents/energy/audit_agreement Accessed June 23, 2011

\section{(Endnotes)}

${ }^{1}$ Natural Resources Defense Council. Greening Advisor: Energy Audits. http://www.nrdc.org/enterprise/greeningadvisor/en-audits.asp (accessed Jun 23, 2011)

${ }^{2}$ American Society of Heating, Refrigerating and Air-Conditioning Engineers, Inc. (ASHRAE). Procedures for Commercial Building Energy Audits (2004)

${ }^{3}$ California Energy Commission, How to Hire an Energy Auditor Handbook (2000). http://www.energy.ca.gov/reports/efficiency_ handbooks/400-00-001C.PDF (accessed Jun 23, 2011)

${ }^{4}$ ASHRAE 2004 above

${ }^{5}$ U.S. Department of Energy. Overview of Potential Energy-Efficiency Measures. http://apps1.eere.energy.gov/buildings/publications/pdfs/rebuild_america/rba_potential_energy_efficiency.pdf (accessed Jun 23, 2011) 


\section{Appendix A}

\section{A Guide to Energy Audits: \\ Request for Qualifications}




\section{Request for Qualifications}

[COMPANY] is issuing this Request for Qualifications ("RFQ") in search of consultants and firms that have expertise and experience in the field of energy efficiency upgrades to buildings and building equipment. Experienced firms are invited to provide the information listed in this RFQ to [DEPT, NAME]. Firms will be placed on a list of available resources for businesses and building owners to contact for assistance in: ASHRAE Level 2 building energy audits, retro-commissioning studies, equipment design engineering, insulation and specialized roofing, lighting retrofits, HVAC equipment optimization, energy management system design, geothermal heat systems, window repairs and weatherization and air sealing. Please provide all requested information, in addition to any relevant company brochures.

1) Business Name:

2) Business Address:

3) Business Phone:

Fax:

Email:

4) List of Principles and Titles:

5) List all activities/projects your business has completed in [CITY]:

6) List and describe any projects your business has completed in [REGION]:

7) Describe projects in which your business has achieved substantial reductions in building energy usage; including insulation, lighting, weatherization, HVAC, building automation controls, occupancy sensors, and energy monitoring: (you may attach project descriptions if available) 
8) List Insurance Coverage(s):

9) How many years has the company been in business?

10) Please attach copies of all associated licenses \& certifications held by your organization:

- ASHRAE Building Energy Assessment Professional

- ASHRAE Building Energy Modeling Professional

- ASHRAE Building Operations \& Performance Management Professional

- ASHRAE Commissioning Process Management Professional

- Professional Engineer's License

- B.P.I Certification

- Massachusetts Contractors License

- Massachusetts Construction Supervisors License

• Energy Audit E.M.S

- Workers Compensation Certificate of Insurance

- Better Business Bureau Membership Certificate

- Other-Please list:

11) List any citations, judgments, claims or any other suits pending against your organization:

12) Please list five customer references we could speak to about the work done by your company. Provide customer's full name, address, phone numbers, and a brief description of work performed for each reference.

For additional information, please contact: 


\section{Appendix B}

\section{A Guide to Energy Audits:}

Request for Qualifications

Energy Audit to Identify Energy Efficiency Projects 


\section{REQUEST FOR PROPOSALS}

\section{Energy Audit to Identify Energy Efficiency Projects}

The < company> requests proposals to be submitted for the following purpose and in accordance with each of the terms and conditions that are attached and incorporated in this Request for Proposals (RFP).

Important information is contained in the various sections of this proposal. These include:

Section I Introduction and Administrative Requirements

Section II Background

Section III Work Statement and Deliverables

Section IV Proposal Format

Section V Minimum Administrative Requirements*

Section VI Instructions for small business, minority, women and/or disabled veteran business enterprise (if applicable)*

Section VIII Evaluation and Selection Process

Section IX Sample Contract Terms*

* Sample sections not included in this appendix. These sections are common to all RFPs released by your organization.

\section{Section I}

\section{Introduction and Administrative Requirements}

\section{Introduction}

\section{A. Background}

The <company> wants to identify ways to reduce energy use and costs in its facilities through a wide range of energy projects. We want to use any utility incentives that might be available for the recommended projects. The contractor will coordinate with (name of utility) to ensure that the recommendations meet all utility program requirements. The contractor will supply all assistance needed from initial identification to actual installation of the energy projects.

\section{B. RFP Purpose}

This Request for Proposals (RFP) will result in the selection of a contractor who will:

- Assist < company>in development of an implementation strategy

- Prepare an energy audit that will identify cost-effective energy efficiency opportunities in the buildings described in Section II

- Develop performance specifications or other design documents needed to bid and install the measures

- Review vendor bids and select qualified equipment contractors

- Manage and commission the projects

\section{Budgeted Funds}

There is a maximum of $\$$ available. This is an hourly rate plus cost reimbursement contract with a ceiling on the total contract amount. 


\section{Responses to RFP}

Responses to this solicitation will be according to the format described in Section IV. The bidder's response shall document its qualifications to perform the tasks described in the Work Statement, Section III.

\section{E. Contact Person}

Questions or clarifications about this RFP should be directed to:

\section{F. Tentative Schedule}

RFP released

Pre-bid meeting or site walk-through

Proposals due no later than pm

Notification of short list firms

Interviews (if needed)

Contractor selected

Contract start date

Required project completion date

\section{Administrative Information}

\section{A. Small Business, Minority, Women, Disabled Veteran Business Enterprises}

State any requirements

\section{B. $<$ Company > Can Cancel}

The City reserves to right to do any of the following:

- cancel this RFP,

- modify this RFP as needed, or

- reject any or all proposals received

\section{Contract Term}

The successful bidder must begin work within one week after the City awards the contract from this RFP. The contract will be effective for up to years, from the commencement of the contract term.

\section{Final Contract}

At the <company's $>$ discretion, the content of this RFP may be incorporated into the final contract.

\section{E. Cancellation}

The City reserves the right to cancel any contract awarded through this RFP by providing 30 days notice to the successful bidder.

\section{F. Verbal}

Any verbal communication from City employees concerning this RFP is not binding and shall not alter a specification, term or condition of this RFP.

\section{G. Bidders' Cost}

The cost of developing a proposal is each bidder's responsibility and cannot be charged to the <company $>$. 


\section{H. Conference}

A Pre-bid Conference and site walk-through will be held on , at at

All prospective bidders are invited to attend this conference or to send representatives to the same.

\section{Due Date}

Deliver typed copies to the <company $>$ of Contracts Office, , no later than , at pm. All bids must be complete when submitted. Facsimile (FAX) transmissions may not be accepted in whole or in part under any circumstances.

\section{J. Withdrawal}

A bidder may, by letter to the Contact Person, withdraw or modify a submitted proposal prior to the due date.

\section{K. Documents}

The successful bidder will be required to submit and/or prepare a few standard documents and statements prior to the contract award. The following standard documents are included in this RFP for informational purposes:

\section{L. < company> Property}

All proposals and related material submitted in response to this RFP become the property of the <company $>$ and are a public record.

\section{Immaterial Defect}

The <company> may waive any immaterial defect or deviation contained in a bidder's proposal. The <company>'s waiver shall in no way modify the RFP or excuse the successful bidder from full compliance.

\section{N. Subcontractors}

If a bidder intends to use subcontractors to conduct any of the work described in the proposal, the bidder must identify the subcontractor, provide a summary of each subcontractor's qualifications, experience and duties that would be performed.

\section{O. Negotiations}

The <company > will begin negotiations with the top ranked bidder(s) for an acceptable fee and contract. The bidder(s) will be required to submit a list of contractor rates after written notification of selection. If negotiations with the top ranked bidder(s) fail, the <company> will enter into negotiations with the next highest ranked bidder, and so on.

\section{P. Contract Award}

The contract shall be awarded to the proposer who satisfies the technical criteria, format and all administrative requirements, and whose cost are acceptable to the <company>. Bidders must achieve a minimum technical score of points in order to be considered in the cost negotiation phase. Details of the selection process are contained in Section VIII. 


\section{Section II \\ Background}

\section{A. About This Section}

This section provides prospective bidders with information about the <company $>$ facilities to be analyzed and the reasons for the audit.

\section{B. Organizational Information}

The < company> operates buildings totaling about square feet. The Department is responsible for maintaining and operating these buildings. Some energy projects have been installed by <company $>$ staff in the past.

These include:

\section{Organization Goals}

Our < company $>$ is interested in an energy audit because of the following reasons (List your goals, objectives, expectations and needs and how information will be used):

\section{Building Information}

Describe each building by including the following:

- Name of building, year built and number of stories

- Daily and annual operating schedules

- Annual energy cost

- Square footage of heated and/or cooled spaces

- Overall types and sizes of HVAC units

- Special uses, such as, kitchen, laundry, pool

- Special equipment, such as, cogeneration

- Special concerns, such as, asbestos

\section{Example Building Information}

The building to be audited consists of the <company > . Floor plans are available for all of these buildings and can be reviewed by contacting The <company> are approximately 130,000 square feet. It has 11 stories and is constructed of concrete. The building's operating daily and annual operating hours are The annual electric and gas use is summarized on Table Mechanical equipment include: a) two Carrier centrifugal chillers, run in parallel, and rated at 150 tons each; and b) two natural gas fired boilers rated at 1.5 million BTUs per hour each. The chillers use R-11 and reject condenser heat to a cooling tower, rated at 185 tons, located on the roof. Most of the building is supplied by a chill water loop that supplies the coils on 4 constant volume air handling units. The HVAC system utilizes a hot water reheat system. 


\section{Section III Work Statement and Deliverables}

\section{A. Introduction}

When directed by the <company>'s project manager, the contractor will:

- Prepare an energy audit for the buildings identified Section II

- Prepare performance specifications and other design documents for selected projects identified in the energy audit, as determined by the <company>'s project manager

- Assist the <company> with implementation of the projects such as bid review and selection, project management and commissioning.

The scoring criteria in this RFP is designed to favor contractors who demonstrate the highest level of experience and expertise in each of the technical areas outlined in the work statement.

\section{B. Tasks}

\section{Site Visit/Initial Meeting}

The contractor will conduct a site visit for the purpose of completing a detailed energy audit of the <company>'s lighting and HVAC systems at the buildings described in Section II. The site visit will include: gathering historical data of existing energy use, meeting with the facilities' staff, touring the facilities, identifying all major lighting and HVAC equipment and systems, determining occupancy schedules and energy use patterns, and identifying facility or occupancy changes that could affect energy use.

At the site visit the contractor will learn how the <company> intends to implement its energy projects and to assess the best form to present the information. After the initial site visit meeting, the contractor will develop a preliminary list of projects and fax (or send) it to the <company>'s Project Manager. Once the list is transmitted, the contractor will call the <company>'s Project Manager to discuss the list and any details that could potentially affect the outcome of any tasks in this work statement. The contractor will not proceed with subsequent tasks under this work statement until the <company>'s project manager has approved of the preliminary project list.

\section{Perform Analysis}

The contractor will perform an analysis of the lighting and HVAC equipment at the <company> facilities described in Section II. The analysis will follow the California Energy Commission's Guide to Preparing Feasibility Studies for Energy Efficiency Projects, May 1996 (Guide). An energy use balance will be prepared for each building for electri<company> and natural gas. Analyses will be performed to determine which, if any, energy efficiency project options are cost effective. Each project will be discussed on a building-by building basis with separate savings and cost.

The analysis will also address the following specific concerns:

All project cost analysis shall include cost of material, labor, engineering design, project management and commissioning of the measures.

\section{Energy Audit Preparation}

Following the Guide, the contractor will prepare an energy audit that describes the facility and its energy use patterns, identifies all cost effective lighting and HVAC options, presents recommendations regarding all options analyzed, and includes all calculations conducted in support of the analyses. The audit will be formatted to allow the <company> to use it as a basis for bidding 
the projects. As most of the identified projects will be implemented using outside contractors, the work should be divided into logical and biddable tasks.

\section{Draft Energy Audit and Comments}

The contractor will provide draft copies of the energy audit to the <company>'s project manager. At the request of the $<$ company>'s project manager, the contractor will meet with the <company $>$ to discuss the audit and identify projects needing performance specifications.

\section{Final Energy Audit and Specifications}

The contractor will incorporate changes and recommendations from the <company $>$ staff and finalize the audit, delivering three copies to the <company>'s project manager. After receiving approval from the <company>'s project manager, the contractor will work with the <company> to develop performance specifications for the recommended projects. The performance specifications should contain, at a minimum, the information specified in Appendix B of the California Energy Commission publication How to Hire an Energy Auditor. The specifications should be in a form that can be included in the <company>'s bid documents to hire an equipment contractor to design or install the projects. The contractor will provide the specifications on a 3.5 inch diskette in a software program specified by the <company>'s project manager. The contractor will work with the engineering design firm as needed and be available by telephone for questions that may arise at the bidder's conference.

\section{Select Equipment Installer}

The contractor will assist the <company>'s project manager in evaluating all equipment bids and identifying proposals that meet the <company>'s technical and administrative requirements.

\section{Project Management \& Commissioning}

The contractor will manage all phases of the energy project. Typical tasks will include, but not be limited to:

- Maintain project schedules

- Plan and track project budgets

- Perform construction review, cost and value analysis

- Coordinate and monitor the work of all equipment installers for compliance with federal, state and local regulations

- Conduct final testing and commissioning

- Recommend final project acceptance

\section{DELIVERABLES AND DUE DATES}

Tentative Due Dates

Task 1: Visit the Site, Prepare Preliminary Project List

Task 2: Perform Energy Audit Analysis

Task 3: Prepare Audit

Task 4: Write Draft Energy Audit.

Task 5: Final Energy Audit and Performance Specifications

Task 6: Evaluate and Select Equipment Installers.

Task 7: Provide Project Management and Commissioning .

\section{Meetings}

At the request of the <company>'s project manager, the contractor shall be available for meetings or briefings to <company $>$ staff or others. 


\section{Amendments}

Any contract amendments shall require prior review and approval by the <company>'s project manager.

\section{Payment Conditions}

The <company>'s project manager will specify the invoice format, such as:

- No payment will be made in advance of receiving a satisfactory final energy audit as determined by the <company>'s project manager.

- Progress payments will be made upon receipt of draft and final energy audits submitted to and approved by the <company>'s project manager, based on time and materials. A request for payment must include an itemized invoice with cost backup and travel receipts attached. Ten percent of the amount invoiced will be withheld until the end of the contract term.

\section{Section IV PROPOSAL FORMAT}

\section{Introduction}

This section provides information on how to prepare a bid in response to this RFP. These instructions prescribe the mandatory proposal format. Instructions must be adhered to, all questions must be answered, and all requested data must be supplied. Proposals that fail to meet these requirements and do not answer all questions will be eliminated from the evaluation process.

\section{Mandatory Format}

The proposal shall be organized as follows:

\section{Cover Letter}

2. Table of Contents

3. Summary of Approach and Technical Staff

4. Contractor Experience

5. Company Organization

6. Personnel Qualifications and Resumes

7. Approach to Tasks in Work Statement

8. Conflicts of Interest

9. List of References

10. Sample Audits

11. Completed <company $>$ Documents and Statements

\section{Cover Letter}

The cover letter must be signed by a person having the authority to commit the bidder to a contract and include:

A summary of the bidder's ability to perform the services described in the Work Statement, Section III.

A statement that the bidder is willing to perform those services and enter into a contract with the <company $>$. 


\section{Table of Contents}

Each proposal must include a Table of Contents organized in the order cited in this "Mandatory Format" section and with page numbers.

\section{Summary}

Summarize your company's overall approach to the Work Statement, highlighting any outstanding features, qualifications and experience relevant to performing the technical work, including the project management. Discuss your current job commitments and how your company can complete the work discussed in this RFP according to the schedule in Section III.

Provide a short description of each staff member who will be doing work on this contract. Highlight any specialized energy expertise that is applicable to the tasks outlined in the Work Statement.

\section{Contractor Experience}

- Describe your company's experience in preparing energy audits for <company> governments. Include your project implementation experience in engineering and design, project and construction management and commissioning.

- Give examples of work performed within the past 36 months that is similar to that indicated in the Work Statement (Section III). Explain its relevance to the Work Statement and the proposed contract.

- Provide a minimum of three references for whom you have provided services similar to that requested in this RFP. If possible, include references for which you have prepared the energy audit and designed, managed and commissioned the resulting projects. For each reference, indicate the company, contact person, telephone, nature of the service or work provided, date of service, and project status.

- Highlight any additional experience that you believe is relevant to the work under this contract.

\section{Company Organization}

- Describe your company structure.

- Describe reliability, continuity, professional awards, location of your company and subcontractors, if any. Include type of company, composition, functions to be performed by members of your company and subcontractors and how they pertain to this contract.

- Describe any electronic reporting, Internet capabilities or other tools that would facilitate communicating information to the <company>.

- Provide an organizational chart for your company. Briefly explain the relationship of each technical staff member and subcontractors, if any, to your company.

\section{Personnel Qualifications}

- Complete Form 2A by listing all individuals in your company who will provide technical services through this contract. Indicate the specific tasks that they will be assigned. Include each individual's job classification, academic degrees, professional registration, areas of contract responsibility, and percentage of time on a monthly basis that the individual will work on the contract tasks.

A proposal that shows a balance of staff time between both senior and more junior levels will rank higher than one that does not.

- Describe the relevant experience each technical staff member had in performing pertinent tasks identified in the Work Statement.

- Provide a current resume or biographical sketch for all personnel who will be assigned to this contract. 
Form 2A: Contractor Staff Qualifications

\section{Contractor Name:}

\begin{tabular}{|l|l|l|l|l|l|l|}
\hline $\begin{array}{l}\text { Bidder's Staff } \\
\text { Name and Title }\end{array}$ & Degrees & $\begin{array}{l}\text { Professional } \\
\text { Affiliations and } \\
\text { Licenses }\end{array}$ & Specialties & $\begin{array}{l}\text { Assigned Work } \\
\text { Statement } \\
\text { Area }\end{array}$ & $\begin{array}{l}\text { Total Years } \\
\text { of Relevant } \\
\text { Experience }\end{array}$ & $\begin{array}{l}\text { Percentage of Time Available for this } \\
\text { Contract* }\end{array}$ \\
\hline & & & & & & \\
\hline & & & & & & \\
\hline & & & & & & \\
\hline
\end{tabular}

* Percentage of time contractor's staff will be available each month to work on this contract.

\section{Approach}

- Describe approach to providing services in the Work Statement.

- Based on the facility description in Section II, discuss the information to be collected and the process to be followed to complete the Work Statement. Explain the general type of recommendations you believe are appropriate for the facilities listed in Section II.

- Describe data collection equipment (i.e. flue gas analyzer, amp/watt meter, light meter, anemometer, etc.) to be used to accomplish the tasks listed in the Work Statement.

- Indicate the building simulation program to be used to accomplish the tasks in the Work Statement.

\section{Conflicts of Interest}

Indicate any relationships with equipment manufacturers or vendors, Energy Services Companies or equipment maintenance firms. The <company > reserves the right to reject any or all proposals that present a true or apparent conflict of interest.

\section{Sample Audits}

Attach one relevant example of prior work. This example should be similar in scope to the work requested in this RFP.

\section{Required Documents}

Complete and submit the following < company> documents: 


\section{SECTION VIII \\ EVALUATION AND SELECTION PROCESS}

\section{Introduction}

Each proposal shall be evaluated on how well it meets the <company>'s needs as described in this RFP. The <company> reserves the right at any time to reject any or all proposals.

\section{Evaluation Stages}

To analyze all proposals, the <company> will organize a committee with expertise in evaluating consulting services. The committee will analyze proposals in the following stages:

\section{A. Administrative}

After the submittal period closes, each proposal received before the deadline is opened and examined to see if it complies with the RFP administrative and format requirements in Sections IV to VI.

\section{B. Technical}

Technical proposals meeting the administrative requirements are evaluated and score based on the criteria on page A-17. The committee identifies those proposals that meet or exceed the required minimum technical points. Point calculations reflect the averages of the combined scores of all evaluators.

\section{Interviews}

The committee may use patterned questions to conduct bidder interviews; bidder responses will be scored. Upon completion of the interviews, the <company> may make adjustments to the scores and re-rank the top competitors.

The committee may reject all bidders and proposals if none are considered in the best interest of the <company>.

\section{Scoring}

The criteria stated under Weighting Factors and Criteria are used in the evaluation of the technical proposal. The technical proposal must attain the minimum score of to pass. Those not attaining the minimum are eliminated from further competition.

The Committee will award points based on:

- Exceptional: 90 to 100 percent of maximum points for the criterion. The proposal satisfies the requirements and describes specifically how and what will be accomplished in a superior manner, both quantitatively and qualitatively, using sample products and illustrative materials such as diagrams, charts and graphs.

- Above Average: 51 to 90 percent of maximum points for the criterion. The proposal satisfies the requirement and describes specifically how and what will be accomplished in an exemplary manner, using sample products and illustrative materials such as diagrams, charts and graphs.

- Average: 50 percent of maximum points for the criterion. The proposal satisfies the requirements and describes generally how and/or what will be accomplished.

- Below Average: 25 to 49 percent of maximum points for the criterion. The responses are minimally acceptable.

- Fail: less than 25 percent of maximum points for the criterion. The proposal is not in substantial accord with the RFP requirements; will have significant effect on the amount paid, or the quality or quantity of products or services; or provides an advantage to one competitor over the other competitors. 


\section{Weighting Factors and Criteria}

\begin{tabular}{|c|c|c|}
\hline Criterion & Key Elements & Points \\
\hline $\begin{array}{l}\text { Approach } \\
\text { to Work } \\
\text { Statement }\end{array}$ & $\begin{array}{l}\text { - Demonstrated understanding of tasks outlined in work statement } \\
\text { - Demonstrated experience with similar tasks } \\
\text { - Audit approach, analysis and recommendations } \\
\text { - Ability to satisfy time lines for deliverables }\end{array}$ & 40 \\
\hline $\begin{array}{l}\text { Company } \\
\text { Technical } \\
\text { Experience }\end{array}$ & $\begin{array}{l}\text { - Quality and relevance of experience in conducting energy audits for local governments } \\
\text { - Depth, relevance and quality of work examples } \\
\text { - References } \\
\text { - Depth of relevant project implementation experience }\end{array}$ & 60 \\
\hline $\begin{array}{l}\text { Company } \\
\text { Organization }\end{array}$ & $\begin{array}{l}\text { - Organizational strengths of proposed company } \\
\text { - Appropriate level and type of staff to complete work in a competent and timely manner. }\end{array}$ & 25 \\
\hline $\begin{array}{l}\text { Personnel } \\
\text { Qualifications } \\
\text { and } \\
\text { Experience }\end{array}$ & $\begin{array}{l}\text { - Qualifications of assigned personnel } \\
\text { - Experience of assigned personnel } \\
\text { - Availability of assigned personnel }\end{array}$ & 25 \\
\hline Interview & $\begin{array}{l}\text { - Response to questions } 50 \\
\text { - Quality of presentation } \\
\text { - Explanation of approach to work statement tasks }\end{array}$ & 50 \\
\hline TOTAL & & 200 \\
\hline
\end{tabular}




\section{Appendix C}

\section{A Guide to Energy Audits: \\ Energy Audit Agreement}




\section{[MODEL] ENERGY AUDIT AGREEMENT}

This Energy Audit Agreement ("Agreement"), effective the last date signed below, is by and between the [agency], an agency of the State of Florida with an office at [address] (the "Agency") and [company] with an office at [address] (the "Company") (each a "Party" and collectively the "Parties").

Whereas, the Company is party to the state term contract procured by the State of Florida, Department of Management Services, ITN No. DMS 01/2002-103, Comprehensive Energy Strategy, which enables the Company to perform work under the Guaranteed Energy Performance Savings Contract Act, codified at section 489.145 of the Florida Statutes, and under section 235.215 of the Florida Statutes; and

Whereas, the Agency is responsible for the operation, management and maintenance of the facilities identified on Attachment A to this Agreement (the "Facility(s)"); and

Whereas, a comprehensive investment grade technical energy audit (the "Energy Audit") and savings analysis (the "Report") must be performed at the Facility in order to determine the feasibility of entering into a guaranteed energy performance savings contract ("Energy Performance Contract") to provide for the installation and implementation of energy conservation measures ("ECMs") at the Facility; and

Whereas, if the ECMs are demonstrated to be feasible, and if the amount of energy cost savings can be reasonably ascertained and guaranteed in an amount sufficient to cover all costs associated with an energy performance contracting project at the Facility(s), the Parties intend to negotiate an Energy Performance Contract under which the Company shall design, procure, install, implement, maintain and monitor such ECMs at the Facility(s);

Therefore, the Parties agree as follows:

\section{Article 1: Scope of Energy Audit}

The Company will perform the Energy Audit and prepare the detailed engineering and economic Report that specifically identifies the energy improvements and operational changes which are recommended to be installed or implemented at the Facility(s). The Report shall contain detailed projections of energy and cost savings to be obtained at the Facility(s) as a result of the installation of the recommended ECMs. The savings calculations must utilize assumptions, projections and baselines which best represent the true value of future energy or operational savings for the Facility(s), i.e., utilize: accurate marginal cost for each unit of savings at the time the audit is performed; documented material and operational costs actually avoided; adjustments to the baseline to reflect current conditions at the Facility(s) compared to the historic base period; calculations which account for the interactive effects of the recommended ECMs; etc. The Report shall clearly describe how utility tariffs were used to calculate savings for all ECMs. The Report shall describe the Company's plan for installing or implementing the measures in the Facility(s), including all anticipated costs associated with such installation and implementation. The primary purpose of the Report is to provide an engineering and economic basis for negotiating an Energy Performance Contract between the Agency and the Company; however, the Agency shall be under no obligation to negotiate such a contract.

The Company shall perform the following tasks in performing the Energy Audit and preparing the Report:

\section{A. Collect General Facility(s) Information}

The Company shall collect general Facility(s) information such as: size, age, construction type, condition and general use of the Facility(s). The Company shall also collect and summarize Facility(s) utility cost and consumption data for the most recent 24-36 month period. Company shall evaluate the impact on utility cost and consumption of any energy initiatives currently being installed or currently planned to be installed by the Agency in the Facility(s) which will remain separate from the Energy

Performance Contract throughout the duration of that agreement. 
Agency shall make available (or cause its energy suppliers to make available) all available records and data concerning energy and water usage for the Facility(s) for the most current 24-36 month period, if available, including: Utility records; occupancy information; descriptions of any changes in the structure of the Facility(s) or its heating, cooling, lighting or other systems or energy requirements; descriptions of all major energy and water consuming or energy and water saving equipment used in the Facility(s); any comfort problems, code deficiencies and description of energy management procedures presently utilized. The Agency shall also make available a record of any energy related improvements or modifications that have been installed during the past three years, or are currently being installed or are currently planned to be installed by the Agency in the Facility(s) separate from the energy service agreement throughout the duration of that agreement. The Agency shall also make available copies of drawings, equipment logs and maintenance work orders to the Company.

\section{B. Analyze Existing Systems and Equipment}

Company shall compile an analysis based on a physical inspection of the major electrical and mechanical systems at the Facility(s), including:

1. Cooling systems and related equipment

2. Heating and heat distribution systems

3. Automatic temperature control systems and equipment

4. Air distribution systems and equipment

5. Outdoor ventilation systems and equipment

6. Kitchen and associated dining room equipment, if applicable

7. Exhaust systems and equipment

8. Hot water systems

9. Electric motors $5 \mathrm{HP}$ and above, transmission and drive systems

10. Interior and exterior lighting

11. Laundry equipment, if applicable

12. Water consumption end uses, such as restroom fixtures, water fountains, irrigation, etc.

13. Other major energy using systems, if applicable

The analysis shall address the following considerations:

1. the loads, efficiencies or hours of operation for each system (where Facility(s) operating or climatic conditions necessitate, engineering estimates may be used, but for large fluctuating loads with high potential savings appropriate measurements are required unless waived by the Agency);

2. current operating condition for each system;

The Company shall conduct interviews with Facility(s) operation and maintenance staff regarding the Facility(s)'s mechanical systems operation, occupancy patterns and problems with comfort levels or equipment reliability.

\section{Establish Base Year Consumption and Reconcile with End Use Consumption Estimates}

Company shall examine the most recent 24-36 months of utility bills and establish Base Year consumption for electricity, fossil fuels and water by averaging; or selecting the most representative contiguous 12 months. Company shall consult with Facility(s) staff and account for any unusual or anomalous utility bills which may skew Base Year consumption from a reasonable representation. 
Company shall analyze loading, usage and/or hours of operation for all major end uses representing more than $5 \%$ of total Facility(s) consumption including, but not limited to:
1. Lighting
2. Heating
3. Cooling
4. HVAC motors (fans and pumps)
5.plug load (independent devices greater than 5\%)
6. kitchen equipment
7. other equipment
8. miscellaneous

Where loading and/or usage are highly uncertain Company shall employ spot measurement and/or short term monitoring at its discretion, or at the request of the Agency. Reasonable applications of measurement typically include variable loads that are likely candidates for conservation measures, such as cooling equipment.

\section{Develop List of Potential Energy Conservation Measures (ECMs)}

1. identify and propose potential ECMs for installation or implementation at the Facility(s), including water conservation measures

2. estimate the cost, savings and life expectancy of each proposed ECM;

3. specify Facility(s) operations and maintenance procedures which will be affected by the installation/implementation of the proposed ECMs;

4. provide analysis methodology, supporting calculations and assumptions used to estimate savings, which shall be based on the life cycle cost calculations provided in section 255.255 of the Florida Statutes. Manual calculations should disclose essential data, assumptions, formulas, etc. so that a reviewer could replicate the calculations based on the data provided;

5. for savings estimates using computer simulations, Company shall provide access to the program and all inputs and assumptions used, if requested by the Agency.

6. provide a preliminary savings measurement and verification plan for each of proposed ECMs

7. provide a preliminary commissioning plan for the proposed ECMs

8. provide detailed calculations for any rate savings proposals

9. provide detailed supporting calculations for any proposed maintenance or other operational savings;

10. estimate any environmental costs or benefits of the proposed ECMs (e.g., disposal costs, avoided emissions, water conservation, etc.)

For all proposed ECMs, Company shall comply with all applicable state, federal and local codes and regulations in effect at the time of this analysis.

\section{E. Select Final Recommended ECMs}

Company shall, in consultation with the Agency, recommend specific ECMs from its preliminary compilation for installation and implementation at the Facility(s). 


\section{F. Cost and Fee Estimates}

Company shall provide detailed estimates of all costs and fees associated with the installation and implementation of the ECMs including:

1. engineering/design costs for individual ECMs

2. contractor/vendor estimates for individual ECM hard costs

3. construction management fees for the project

4. commissioning costs for individual ECMs

5. initial training costs

6. annual service fees including:

- measurement and verification

- maintenance

- performance monitoring

- ongoing training services

7. other costs/fee (specify)

\section{G. Savings Estimates}

The Agency has endeavored to provide the Company with sufficient general and specific guidance in this Article 1 to develop the savings estimates for the Report. In the event that questions arise as to the calculation of savings or whether certain items will be allowed as savings, the Company shall seek written guidance from the Agency. Agency's rejection of certain calculations of savings or rejection of certain items as allowable savings in the Report shall be at the risk of the Company.

The following items will be allowed as savings or in the development of savings: ${ }^{1}$

- Agency material/commodity cost

- Outside maintenance labor cost (if applicable)

- Agreed escalation rates for natural gas

- Agreed escalation rates for electricity

- Agreed escalation rates for water

- Agreed escalation rates for material/commodity cost savings

- Agreed escalation rates for allowable labor savings

The following items will not be allowed as savings or in the development of savings:

- Agency in-house labor cost

- Agency deferred maintenance cost

- Offset of future Agency capital cost

1 Unless otherwise agreed in writing, escalation rates shall tie to the Consumer Price Index. The value of fuel and water unit savings shall be escalated using actual rate increases as they occur over the term of the contract. The base rate value for each fuel and water unit shall not devalue in the event of any rate decrease. 


\section{H. Report Format}

1. An executive summary which describes the Facility(s), measures evaluated, analysis methodology, results and a summary table presenting the cost and savings estimates for each measure.

2. A discussion of measures not evaluated in detail and the explanation of why a detailed analysis was not performed.

3. A summary of all utility bills, Base Year consumption and how it was established, and end use reconciliation with respect to the Base Year including a discussion of any unusual characteristics and findings.

4. Detailed descriptions for each ECM including analysis method, supporting calculations (may be submitted in appendices), results, proposed equipment and implementation issues.

5. Conclusions, observations and caveats regarding cost and savings estimates.

6. Thorough appendices which document the data relied upon to prepare the analysis and how that data was collected.

The Report shall be completed within ninety (90) days of the effective date of this Agreement, unless otherwise stated in Attachment A. The Agency shall conduct and complete a technical review within sixty (60) days of its receipt of the Report, unless otherwise stated in Attachment A.

\section{Acceptance of the Report- If Energy Conservation Measures are Feasible.}

The Agency shall accept the Report if the recommended ECMs are feasible and projected energy cost savings are equal to or greater than the total projected costs of the design and installation of the recommended ECMs. If the Agency determines that one or more of the recommended ECMs is not feasible, the Agency shall give the Company written notice of any and all said objections, in detail, within fourteen (14) days after completing its technical review of the Report. The Company shall correct the Report and submit a revised draft within twenty-one (21) days of said notification. The Agency shall have fourteen (14) days from receipt of the revised Report to notify the Company if any objections have not been corrected. This re-submission process shall continue until (1) the date all material concerns are resolved and the Report is accepted, or (2) the dispute is otherwise resolved.

\section{Article 2: Energy Performance Contract}

The Parties intend to negotiate an Energy Performance Contract under which the Company shall design, install and implement ECMs and provide certain maintenance and monitoring services. However, nothing in this Agreement should be construed as an obligation on any of the Parties to execute such an Energy Performance Contract. The terms and provisions of such an Energy Performance Contract shall be set forth in a separate agreement. This Agreement shall automatically terminate upon the Parties' execution of an Energy Performance Contract relating to the Facility(s).

\section{Article 3: Payment}

The Parties understand and intend that the Company's costs for services performed under this Agreement (1) shall be included in the total project cost, (2) shall not be paid for under this Agreement, and (3) shall be paid for only under the Energy Performance Contract, if any, from savings generated by implemented ECMs. The Company is undertaking work under this Agreement in consideration of the Agency's good faith intention to negotiate the Energy Performance Contract with the Company. The Company understands and agrees that payment to it is contingent upon realization of energy cost savings being equal to or greater than the total cost of the design and installation of the Company's recommended ECMs. 


\section{Article 4: Termination}

\section{A. By Company:}

Company may terminate this Agreement prior to the completion of the Energy Audit and Report or subsequent to the completion of the Energy Audit and Report if:

(i) It determines that it cannot guarantee a minimum amount of energy and cost savings through the implementation of an energy performance contracting project at the Facility(s); or

(ii) It determines that even though it can guarantee a minimum amount of energy and cost savings in energy costs, that amount would be insufficient to cover the costs associated with performing this analysis, installing ECMs and related maintenance and monitoring services.

Termination under this section shall be effective upon Agency's receipt of written notification from the Company stating the reason for the termination and all supporting documents. Company shall provide the Facility(s) with any preliminary notes, reports or analysis which have been produced or prepared prior to the effective date of the termination.

\section{B. By Agency:}

Agency may terminate this Agreement:

(i) If the Company fails to complete the Energy Audit and deliver the Report to the Agency within the time established in Article 1, above; or fails to obtain a written extension of that time from the Agency. Termination under this subsection B (i) shall be effective upon Company's receipt of written notification from the Agency that the deadline for submission of the Report has past. Company shall provide the Facility(s) with any preliminary notes, reports or analysis which have been produced or prepared prior to the effective date of the termination.

(ii) If, prior or subsequent to the completion of the Energy Audit, the Company notifies the Agency in writing that it is unable to guarantee a sufficient level of savings pursuant to subsection 4 A (i) or (ii) above. Termination under this subsection B (ii) shall be effective upon Company's receipt of written notification from the Agency. Company shall provide the Facility(s) with any preliminary notes, reports or analysis which have been produced or prepared prior to the effective date of the termination.

\section{By Either Party:}

Either Party may terminate this Agreement, when the Party deems it to be in its best interest to do so, by providing the other Party thirty (30) days written notice of its intent to do so. Termination shall be effective thirty (30) days after receipt of the written notice.

\section{Article 5: Standard Terms and Conditions}

\section{Section 1. Agreement Term}

The Agreement term shall commence on the effective date of the Agreement and end on [date], unless earlier terminated pursuant to the provisions of Article 4 hereof. Notwithstanding, Company shall adhere to the deadlines set forth in Article 1 regarding the completion and submittal of the list of ECMs and the Report.

\section{Section 2. Appropriations}

Obligations of the Agency shall cease immediately without penalty if in any fiscal year covered by the Agreement term, the Agency fails to appropriate, reappropriate or otherwise make available funds for this Agreement. Agency shall provide written notification to Company of any impending change in the status of appropriations which may affect this Agreement of which it has notice.

\section{Section 3. Materials, Equipment and Supplies}

The Company shall provide or cause to be provided all facilities, materials, equipment and supplies necessary to perform the Energy Audit and prepare the Report. 


\section{Section 4. Subcontractor Disclosure}

As of the execution date of this Agreement, the following subcontractors are expected to perform material work (i.e., greater than $5 \%$ of the total work) pursuant to this Agreement:

[subcontractor]

[address]

If, during the term of this Agreement, the Company retains subcontractors to perform material work pursuant to this Agreement who were not disclosed, the Company shall so notify the Agency in writing.

\section{Section 5. Patent and Copyright Responsibility}

The Company agrees that any material or design specified by the Company or supplied by the Company pursuant to this Agreement shall not knowingly infringe any patent or copyright, and the Company shall be solely responsible for securing any necessary licenses required for patented or copyrighted material utilized by the Company in the performance of the Energy Audit and preparation of the Report.

\section{Section 6. Release and Indemnity}

The Company agrees to assume all risk of loss and to indemnify and hold the Agency, its officers, agents and employees harmless from and against any and all liabilities, demands, claims, suits, losses, damages, causes of action, fines or judgments, including costs, attorneys' and witnesses' fees, and expenses incident thereto, for injuries to persons (including death) and for loss of, damage to or destruction of property (including property of the Agency) because of Company's negligent or intentional acts or omissions. In the event that any demand or claim is made or suit is commenced against the Agency, the Agency shall give prompt written notice thereof to Company and Company shall have the right to compromise or defend the same to the extent of its own interest. Company further agrees to maintain adequate insurance to protect the Agency against such risks. Company also agrees to indemnify and hold the Agency harmless should any goods or services provided by Company infringe upon the patent, copyright or trade secret of another. Notwithstanding any provision to the contrary, neither Party shall be liable to the other Party for any special, incidental, consequential, or punitive damages.

\section{Section 7. Lobbying, Integrity, and Retention of Records}

Pursuant to section 216.347 of the Florida Statutes, the Company may not expend any State funds for the purpose of lobbying the Legislature, the judicial branch, or a state agency. In addition, the Company shall not, in connection with this or any other agreement with the State, directly or indirectly (1) offer, confer, or agree to confer any pecuniary benefit on anyone as consideration for any State officer or employee's decision, opinion, recommendation, vote, other exercise of discretion, or violation of a known legal duty, or (2) offer, give, or agree to give to anyone any gratuity for the benefit of, or at the direction or request of, any State officer or employee. For purposes of clause (2), "gratuity" means any payment of more than nominal monetary value in the form of cash, travel, entertainment, gifts, meals, lodging, loans, subscriptions, advances, deposits of money, services, employment, or agreements of any kind. Upon request of the Agency's Inspector General, or other authorized State official, the Company shall provide any type of information the Inspector General deems relevant to the Company's integrity or responsibility. Such information may include, but shall not be limited to, the Company's business or financial records, documents, or files of any type or form that refer to or relate to the Agreement. The Company shall retain such records for the longer of (1) three years after the expiration of the Agreement or (2) the period required by the General Records Schedules maintained by the Florida Department of State (available at: $h t t p: / / d l i s . d o s . s t a t e . f l . u s / b a r m / g e n s c h e d u l e s / g e n s c h e d . h t m$ ). Failure to maintain the books, records, and supporting documents required by this Section shall establish a presumption in favor of the Agency for the recovery of any funds paid by the Agency under the Agreement for which adequate books, records, and supporting documents are not available to support their purported disbursement. The Company agrees to reimburse the State for the reasonable costs of investigation incurred by the Inspector General or other authorized State official for investigations of the Company's compliance with the terms of this or any other agreement between the Company and the State which results in the suspension or debarment of the Company. Such costs shall include, but shall not be limited to: salaries of investigators, including overtime; travel and lodging expenses; and expert witness and documentary fees. The Company shall not be responsible for any costs of investigations that do not result in the Company's suspension or debarment. 


\section{Section 8. Dispute Resolution}

The Agency and the Company recognize and acknowledge that efforts should always be made to avoid or prevent disputes through effective partnering, good communications, and joint decision making; and that timely requests for clarification and for information will help ensure a better understanding of issues and problems and lead to the elimination of doubts, uncertainties, and ambiguities. Nevertheless, the Agency and the Company also recognize that disputes may develop between them and, in such event, wish to establish procedures to be followed to resolve such disputes in the shortest possible time and at the least possible expense to the Agency and the Company.

Any conflict or dispute between the Agency and the Company shall be resolved in accordance with the procedures specified in this Agreement, which shall be the sole and exclusive procedures for the resolution of any such disputes. This Agreement establishes successive steps of conflict prevention and alternative dispute resolution prior to litigation, completion of which shall be conditions precedent to the right to commence litigation over any dispute arising out of or relating to the Agreement. The successive steps are: (1) informal negotiations between project-level management personnel; (2) formal negotiations between executive-level management, initiated by written notice and completed within thirty days, or longer as mutually agreed; and (3) mediation, initiated by written notice. Except as otherwise agreed by the Parties in a mediation contract, all mediation proceedings shall be conducted in accordance with this Agreement and, where applicable, the then-current Model Procedure for Mediation of Business Disputes published by the Center for Public Resources (CPR), 366 Madison Avenue New York, NY 10017, (212) 949-6490 (http://www.cpradr.org). If the Agency and the Company have not agreed within ten (10) business days of the request for mediation on the selection of a neutral mediator willing to serve, then the Parties agree that a mediator shall be selected by the Florida Conflict Resolution Consortium (FCRC), Florida State University, Tallahassee, (850) 644-6320 (http://consensus.fsu.edu). The appointment by FCRC of a qualified mediator shall be binding on both Parties, and both Parties shall promptly cooperate with the appointed mediator to effectuate mediation.

Any action legal or equitable action arising out of or relating to this Agreement shall be brought in the appropriate state court in Leon County, Florida, and not elsewhere, and shall be governed by Florida law. The threshold issue for determination shall be whether the Party bringing the action has complied with the alternative dispute resolution processes specified above.

\section{Section 9. Personnel}

All Company employees, subcontractors, or agents performing work under the Agreement shall be properly trained technicians who meet or exceed any specified training qualifications. Upon request, Company shall furnish a copy of technical certification or other proof of qualification. All employees, subcontractors, or agents performing work under the Agreement must comply with all security and administrative requirements of the Agency. The Agency may conduct, and the Company shall cooperate in, a security background check or otherwise assess any employee, subcontractor, or agent furnished by the Company. The Agency may refuse access to, or require replacement of, any personnel for cause, including, but not limited to, technical or training qualifications, quality of work, change in security status, or non-compliance with the Agency's security or other requirements. Such approval shall not relieve the Company of its obligation to perform all work in compliance with the Agreement. The Agency may reject and bar from any facility for cause any of the Company's employees, subcontractors, or agents.

The Company, together with its agents, subcontractors, officers and employees, shall have and always retain under the Agreement the legal status of an independent contractor, and in no manner shall they be deemed employees of the Agency or deemed to be entitled to any benefits associated with such employment. During the term of the Agreement, the Company shall maintain at its sole expense those benefits to which its employees would otherwise be entitled to by law, including health benefits, and all necessary insurance for its employees, including workers' compensation, disability, and unemployment insurance, and provide the Agency with certification of such insurance upon request. The Company remains responsible for all applicable federal, state, and local taxes, and all FICA contributions. 


\section{Section 10. Compliance with Applicable Law}

In performing this Agreement, the Company shall comply with all laws, rules, codes, ordinances, and licensing requirements that are applicable to the conduct of its business, including those of federal, State, and local agencies having jurisdiction and authority. By way of non-exhaustive example, Chapter 287 of the Florida Statutes and Chapter 60A-1 of the Florida Administrative Code govern the Agreement. By way of further non-exhaustive example, the Company shall comply with section 247A(e) of the Immigration and Nationalization Act, the Americans with Disabilities Act, and all prohibitions against discrimination on the basis of race, religion, sex, creed, national origin, handicap, marital status, or veteran's status. Violation of such laws shall be grounds for Agreement termination. The Agency may cancel the Agreement if the Company refuses to allow public access to all records made or received by the Company in conjunction with the Agreement, unless the records are exempt from section 24(a) of Article I of the State Constitution and section 119.07(1) of the Florida Statutes.

\section{Section 11. Waivers}

No right of either party hereto shall be deemed to have been waived by non-exercise thereof, or otherwise, unless such waiver is reduced to writing and executed by the party entitled to exercise such right.

\section{Section 12. Assignment}

Neither Party may assign this Agreement without the prior written consent of the other Party, which shall not be unreasonably withheld.

\section{Section 13. Capacity to Contract}

Each person signing the Agreement warrants that he or she is duly authorized to do so and to bind the respective Party to the Agreement. The Company warrants that it is in good standing and legally authorized to transact business in Florida. The Company warrants that, to the best of its knowledge, there is no pending or threatened action, proceeding, or investigation, or any other legal or financial condition, that would in any way prohibit, restrain, or diminish the Company's ability to satisfy its Agreement obligations. The Company warrants that neither it nor any affiliate is currently on the convicted vendor list maintained pursuant to section 287.133 of the Florida Statutes, or on any similar list maintained by any other state or the federal government. The Company shall immediately notify the Agency in writing if its ability to perform is compromised in any manner during the term of the Agreement.

\section{Section 14. Confidential Information}

Each Party may have access to confidential information made available by the other Party (see particularly, but not exclusively, subsection 119.07(ee) and section 119.071 of the Florida Statutes). Each Party shall protect such confidential information in the same manner as it protects its own confidential information of like kind. Disclosure of any confidential information received by the Agency will be governed by the Public Records Act, chapter 119 of the Florida Statutes.

\section{Section 15. Convicted or Discriminatory Vendors}

A person or affiliate placed on the convicted vendor list following a conviction for a public entity crime is prohibited from doing any of the following for a period of 36 months from the date of being placed on the convicted vendor list: submitting a bid on a contract to provide any goods or services to a public entity; submitting a bid on a contract with a public entity for the construction or repair of a public building or public work; submitting bids on leases of real property to a public entity; being awarded or performing work as a contractor, supplier, subcontractor, or consultant under a contract with any public entity; and transacting business with any public entity in excess of the Category Two threshold amount $(\$ 25,000)$ provided in section 287.017 of the Florida Statutes.

An entity or affiliate placed on the discriminatory vendor list pursuant to section 287.134 of the Florida Statutes may not submit a bid on a contract to provide any goods or services to a public entity; may not submit a bid on a contract with a public entity for the construction or repair of a public building or public work; may not submit bids on leases of real property to a public entity; may not be awarded or perform work as a contractor, supplier, sub-contractor, or consultant under a contract with any public entity; and may not transact business with any public entity.

\section{Section 16. Project Management}

All necessary and ordinary communications, submittals, approvals, requests and notices related to Project work shall be issued or received by: 
[agency]

[address]

[telephone]

[facsimile] [email]

[company]

[address]

[telephone]

[facsimile]

[email]

Either Party may change its point of contact by written notice to other Party's then-current designated contact, which shall not constitute a formal amendment to this Agreement.

\section{Section 17. Modification of Terms}

The Agreement contains all the terms and conditions agreed upon by the Parties. The Agreement may only be modified or amended upon mutual written agreement of the Parties. No oral agreements or representations shall be valid or binding upon the Agency or the Company.

\section{Section 18. Execution in Counterparts}

The Agreement may be executed in counterparts, each of which shall be an original and all of which shall constitute but one and the same instrument.

\section{Section 19. Severability}

If a court deems any provision of the Agreement void or unenforceable, that provision shall be enforced only to the extent that it is not in violation of law or is not otherwise unenforceable, and all other provisions shall remain in full force and effect.

\section{Article 6: Execution}

SO AGREED:

\section{STATE OF FLORIDA} DEPARTMENT OF

By: [name], Secretary

Date

\section{[company]}

By:

Its: 


\section{ve ENEROY}

Energy Efficiency \& Renewable Energy
EERE Information Center

1-877-EERE-INF (1-877-337-3463)

www.eere.energy.gov/informationcenter

For more information, visit:

commercialbuildings.energy.gov/alliances
Commercial Building Initiative 